\title{
Immunotoxicological and neurotoxicological profile of health effects following subacute exposure to geogenic dust from sand dunes at the Nellis Dunes Recreation Area, Las Vegas, NV
}

\author{
Authors: Deborah Keila, Brenda Buckb, Dirk \\ Goossens, Yuanxin Teng, Mallory Leetham, Lacey \\ Murphy, James Pollard, Margaret Eggers, Brett \\ McLaurin, Russell Gerads, \& Jamie DeWitt
}

NOTICE: this is the author's version of a work that was accepted for publication in Toxicology and Applied Pharmacology. Changes resulting from the publishing process, such as peer review, editing, corrections, structural formatting, and other quality control mechanisms may not be reflected in this document. Changes may have been made to this work since it was submitted for publication. A definitive version was subsequently published in Toxicology and Applied Pharmacology, [Volume 291, January 2016] DOI\#10.1016/j.taap.2015.11.020

Keil D, Buck B, Goossens D, Teng Y, Leetham M, Murphy L, Pollard J, Eggers M, McLaurin B, Gerads R, DeWitt J, "Immunotoxicological and neurotoxicological profile of health effects following subacute exposure to geogenic dust from sand dunes at the Nellis Dunes Recreation Area, Las Vegas, NV," Toxicol Appl Pharmacol. 2016 Jan 15 291:1-12.

Made available through Montana State University's ScholarWorks 


\title{
Immunotoxicological and neurotoxicological profile of health effects following subacute exposure to geogenic dust from sand dunes at the Nellis Dunes Recreation Area, Las Vegas, NV
}

\author{
Deborah Keil ${ }^{a}$,*, Brenda Buck ${ }^{b}$, Dirk Goossens ${ }^{b}, c$, Yuanxin Teng ${ }^{b}$, Mallory Leetham ${ }^{a}$, Lacey \\ Murphy ${ }^{\mathrm{a}}$, \\ James Pollard $^{b}$, Margaret Eggers ${ }^{d}$, Brett McLaurin ${ }^{e}$, Russell Gerads ${ }^{f}$, Jamie DeWitt ${ }^{g}$ \\ a Department of Microbiology and Immunology, Montana State University, Bozeman, MT 59717, USA \\ b Department of Geoscience, University of Nevada, Las Vegas, NV 89154, USA \\ C Geography Research Group, Department of Earth and Environmental Sciences, KU Leuven, Belgium \\ d Center for Biofilm Engineering, Montana State University, Bozeman, MT 59717, USA \\ e Department of Environmental, Geographical, and Geological Sciences, Bloomsburg University of Pennsylvania, \\ Bloomsburg, PA 17815, USA \\ f Brooks Rand Labs, LLC, Bothell, WA 98011, USA \\ $\mathrm{g}$ Department of Pharmacology and Toxicology, East Carolina University, Greenville, NC 27834, USA
}

\section{A B S T R A C T}

Exposure to geogenic particulate matter (PM) comprised of mineral particles has been linked to human health effects. However, very little data exist on health effects associated with geogenic dust exposure in natural set-tings. Therefore, we characterized particulate matter size, metal chemistry, and health effects of dust collected from the Nellis Dunes Recreation Area (NDRA), a popular off-road vehicle area located near Las Vegas, NV. Adult female B6C3F1 mice were exposed to several concentrations of mineral dust collected from active and veg-etated sand dunes in NDRA. Dust samples (median diameter: $4.4 \mu \mathrm{m}$ ) were suspended in phosphatebuffered sa-line and delivered at concentrations ranging from 0.01 to $100 \mathrm{mg}$ dust $/ \mathrm{kg}$ body weight by oropharyngeal aspiration. ICP-MS analyses of total dissolution of the dust resulted in aluminum $(55,090 \mu \mathrm{g} / \mathrm{g})$, vanadium $(70 \mu \mathrm{g} / \mathrm{g})$, chromium $(33 \mu \mathrm{g} / \mathrm{g})$, manganese $(511 \mu \mathrm{g} / \mathrm{g})$, iron $(21,600 \mu \mathrm{g} / \mathrm{g})$, cobalt $(9.4 \mu \mathrm{g} / \mathrm{g})$, copper $(69 \mu \mathrm{g} / \mathrm{g})$, zinc $(79 \mu \mathrm{g} / \mathrm{g})$, arsenic $(62 \mu \mathrm{g} / \mathrm{g})$, strontium $(620 \mu \mathrm{g} / \mathrm{g})$, cesium $(13 \mu \mathrm{g} / \mathrm{g})$, lead $25 \mu \mathrm{g} / \mathrm{g})$ and uranium $(4.7 \mu \mathrm{g} / \mathrm{g})$. Arsenic was present only as $\operatorname{As}(\mathrm{V})$. Mice received four exposures, once/week over 28-days to mimic a month of weekend exposures. Descriptive and functional assays to assess immunotoxicity and neurotoxicity were performed $24 \mathrm{~h}$ after the final exposure. The primary observation was that 0.1 to $100 \mathrm{mg} / \mathrm{kg}$ of this sand dune derived dust dose-responsively reduced antigen-specific IgM antibody responses, suggesting that dust from this area of NDRA may present a potential health risk.

\section{Introduction}

The U.S. National Research Council has identified emission source characterization and hazardous component assessment as two of the top ten research priorities for airborne particulate matter (PM; National Research Council, 2004). PM is a global health concern, as these airborne particulates are not contained within national borders. In China, Brazil, Spain and India, human health effects have also been re-ported with exposure to PM2.5 or PM10 (particulate matter b2.5 $\mu \mathrm{m}$ or $\mathrm{b} 10 \mu \mathrm{m}$ in diameter, respectively) containing metals such as lead, zinc, nickel, iron, manganese, chromium, and copper (Kulshrestha et al., 2009; Aldabe et al., 2011; de Miranda et al., 2012; Wang et al., 2013).
Keywords:

Geogenic dust

Heavy metals

Minerals

Lung exposure

Immunotoxicity

Neurotoxicity
Moreover, metals on PM are bioavailable for uptake via human inhala-tion and ingestion (Morman et al., 2009).

The Nellis Dunes Recreation Area (NDRA) is a popular off-road vehi-cle (ORV) driving destination managed by the Bureau of Land Manage-ment (BLM), located just $6 \mathrm{~km}$ northeast of Las Vegas, NV. For the past 40 years, the NDRA has provided the public an accessible area in Clark County for legal off-road driving, with annual visitation estimated at over 300,000 (Goossens and Buck, 2009). Recently, dust at NDRA was found to have abnormally high concentrations of arsenic (Soukup et al., 2012), a metal classified as a human carcinogen (USEPA, 1988). Due to the high visitor rate and potential health risks associated with geogenic dust inhalation exposure, the current study examined the tox-icological effects specific to geogenic dust collected from easily erodible sand dune surfaces at NDRA, designated here as "CBN 1".

CBN 1 surfaces at NDRA are characterized by sand dunes with and without vegetation. Dunes are one of the most 
utilized by both individual recreationists as well as by companies that provide ORV services. They cover an area of approximately 317 ha, among which 57 ha dunes without vegetation and 260 ha partly vegetated dunes. Both dune types are prone to severe wind erosion yearround. Soils at the CBN 1 surfaces contain the typical assortment of arid-soil minerals including quartz, calcite, gypsum, amphibole, feldspar and many clay minerals such as palygorskite, illite, smectite, kaolinite and chlorite (Soukup et al., 2011). These minerals have within their crystal structure or adsorbed on their surfaces, many different heavy metals and metalloids (see Table 1). Dust in this area is generated by both natural wind erosion and ORV activity (Goossens et al., 2012). The geologic source of the dune sand is the yellow sandstone facies of the Muddy Creek Formation, which contains significant arsenic concentrations, especially in the finer grain-size fractions (Goossens et al., 2015). These finer grain-size fractions become airborne as a result of wind or ORV activities, leading to inhalation exposures.

It is only recently that health effects of dust generated from soil sources has emerged as an increasingly important health concern (Sharratt and Lauer, 2006; Whicker et al., 2006; Buck et al., 2013; Derbyshire, 2007). Morman and Plumlee (2013) recognized that particle size alone is insufficient for understanding the risks of particulate matter and that the relative contributions of toxic trace metals and other components of dust to respiratory morbidity and mortality deserve further research. In a large study across 25 U.S. communities, Franklin et al. (2008) used data that combined air quality information from the U.S. Environmental Protection Agency (EPA), mortality data for more than 1.3 million deaths, and U.S. National Climatic Data Center meteorological data, to examine how the association of mortality with PM2.5 differed among communities as a result of variation in the chemical composition of the particulate matter. Mortality increased when nickel, aluminum, sulfate, silicon, and arsenic were in a higher proportion while the combination of sulfate, nickel, and aluminum modified the association between PM2.5 mass and mortality. Furthermore, Ruckerl et al. (2011) cite multiple studies documenting that the metal components of natural dust, such as vanadium, chromium, nickel, copper, and iron, cause oxidative stress thereby inducing proinflammatory effects in the lung.

Many studies have found that exposure to airborne PM increases risks of respiratory illness, cardiovascular disease, and mortality (Dockery et al., 1993; Pope et al., 1995; Samet et al., 2000; Lee et al., 2006; Beelen et al., 2008; Samoli et al., 2008; Ruckerl et al., 2011). Extensive reports identify that a number of air pollutants and particulates cause local pulmonary immune deficits. This is further supported with numerous epidemiologic studies describing increased PM air pollution with increased frequency of respiratory complaints such as pneumonia, asthma, croup, bronchitis and viral pulmonary infections (Brauer et al., 2002; Dockery \& Pope, 1994; Gilmour \& Koren, 2000; Lambert et al., 2003). While it is well-established that airborne PM affects local immune responses in the lung, less is known about systemic immunological effects due to PM exposure (Albright and Goldstein, 1996; Leonardi et al., 2000; Hassani et al., 2004). One study demonstrates that systemic $\operatorname{IgG}$ antibody production is suppressed in an autoimmune mouse following exposure to PM (Hassani et al., 2004).

Geogenic dust also almost always has significant amounts of crystalline silica, primarily in the form of the mineral quartz and any number of other silicate minerals. Silica exposure is associated with a variety of autoimmune problems, including rheumatoid arthritis, lupus, scleroderma, and glomerulonephritis (Lim et al., 2012). Those exposed to crystalline silica in occupational environments present with a disruption in immunological homeostasis that includes increased lymphoproliferative responses, increased levels of the pro-inflammatory cytokines (IFN- $\gamma$, IL- $1 \alpha$, TNF- $\alpha$, IL-6), and increased anti-inflammatory cytokines (IL-10 and TGF- $\beta$; Rocha-Parise et al., 2014). Crystalline silica exposure is also associated with excess mortality from acute renal disease and can also be associated with an increased risk of end-stage renal disease (reviewed by Ghahramani, 2010).

Even fewer studies have characterized neurotoxicity following PM exposure. Calderón-Garcidueñas et al. (2008) report that exposure to elevated concentrations of air pollutants including ultrafine PM and PM2.5 causes neuroinflammation and alters innate immune responses in the brain of children and young adults. Ultrafine PM appears to enhance formation of protein fibrils in the brain affecting beta-amyloid ( $\beta 42)$ and $\alpha$-synuclein (Linse et al. 2007). Extrapulmonary translocation of inhaled PM and metals to the brain have also been reported (Oberdorster et al., 2004; Tjalve and Henriksson, 1999). CalderónGarcidueñas et al. (2008) argue that neuroinflammation as a result of exposure to air pollution could have a causative role in both Alzheimer's and Parkinson's diseases.

As we learn more about geogenic dust and its complexity, it is increasingly important to characterize health effects due to exposures, especially as recreational and developmental pressures increase the number of humans exposed to these dusts. Therefore, this study was designed to establish a toxicological profile following lung exposure via oropharyngeal aspiration to geogenic dust, characterized by size as well as silica and metal content. A suite of immunotoxicological, clinical chemistry, and neurotoxicological evaluations were used to determine the dose-response profile of exposure to NDRA geogenic dust.

\section{Methods}

\subsection{Collection of geogenic dust}

Composite samples were collected from the topsoil (upper 0-4 cm) using a plastic scoop and placed into a clean plastic bag, which was hermetically closed after collection. GPS position of the center of the collection area was recorded for each sampling point. Samples were collected from active sand dunes and sand sheets with no vegetation and dune sands with sparse and isolated shrubs; these correspond to an internal designation for our study described as surface units 1.1 and 1.2 in McLaurin et al., 2011. The samples were treated in a Soil Fine Particle Extractor (see Goossens, 2012) to extract particles with a median diameter of approximately $4 \mu \mathrm{m}$. The extracts were combined to create combination surface unit designated as "CBN 1" based on the areal extent of that surface unit within the dune field: surface unit 1.1: $13.7 \%$, and surface unit 1.2: $86.3 \%$.

\subsection{ICP-MS analyses of geogenic dust}

All samples were digested in accordance with the USGS Four-Acids Method (Briggs and Meier, 1999) and subsequently analyzed using an Agilent 7700 inductively coupled plasma/mass spectrometry (ICP-MS) device (Agilent Technologies, Santa Clara, USA). To ensure quality control for the ICP-MS analyses, all quality control procedures set forth by US EPA Method 6020A (USEPA, 2007) were followed. In addition, NIST

Table 1

Total elemental concentration in dry geogenic dust sample $(\mu \mathrm{g} / \mathrm{g})$ from CBN 1 .

\begin{tabular}{|c|c|c|c|c|c|c|c|c|c|c|c|c|c|c|c|c|c|}
\hline Median $^{\mathrm{a}}$ & $\mathrm{Al}$ & V & $\mathrm{Cr}$ & $\mathrm{Mn}$ & $\mathrm{Fe}$ & Co & $\mathrm{Cu}$ & $\mathrm{Zn}$ & As & $\mathrm{Sr}$ & $\mathrm{Cd}$ & $\mathrm{Sb}$ & Cs & $\mathrm{Tl}$ & $\mathrm{Pb}$ & $\mathrm{U}$ & $\mathrm{Si}$ \\
\hline 4.39 & 55,100 & 70 & 33 & 511 & 21,600 & 9.4 & 69 & 79 & 62 & 620 & $<0.47$ & $<3.0$ & 13 & $<8.3$ & 25 & 4.7 & 197,000 \\
\hline
\end{tabular}

$<$ indicates value is below method quantitation limit (MQL) and that value presented is MQL.

Data are reported with a maximum of three significant figures.

a Median diameter $(\mu \mathrm{m})$. 
SRM 8704 (Buffalo River Sediment) and NIST SRM 2711a (Montana II Soil) were used as standard reference materials (SRMs).

\subsection{Arsenic speciation}

Arsenite, arsenate, monomethylarsonic acid, and dimethylarsinic acid quantification speciation was performed using IC-ICP-CRC-MS at Brooks Rand Labs, LLC (formerly Applied Speciation and Consulting, LLC) according to an in-house developed method based on Kubachka et al. (2012).

\subsection{Quantitation of silicon in geogenic dust}

Analysis for the element silicon utilized a Thermo Scientific Niton XL3t GOLDD + portable XRF (X-ray fluorescence) instrument. For calibration the NIST Standard Reference Material 2711A was run and the $\mathrm{XRF}$ results are in agreement with the certified values for silicon and within the margins of uncertainty for the soil standard. A total of six samples were analyzed from CBN 1 and each sample was run twice for a total of $120 \mathrm{~s}$ for each analysis.

\subsection{Preparation, stability and verification of geogenic dust for animal exposures}

Dust samples were carefully labeled, stored in sealed and dry containers, protected from light, and secured in a lock box in the laboratory. CBN 1 dust was prepared in sterile, endotoxin-free, phosphate buffered saline (ETF-PBS) at concentrations of $0.01,0.1,1,10$, or $100 \mathrm{mg}$ of dust/ $\mathrm{kg}$ of body weight and was administered to mice within $1-2 \mathrm{~h}$ of preparation. Some elements have various degrees of solubility in water and addition of dust samples to saline for delivery into the mouse may have changed the distribution of insoluble elements versus concentration of those elements in solution. To verify that adding the dust samples to PBS did not substantially alter the solubility of elements, a stability study was performed with the lowest concentration $(0.01 \mathrm{mg} / \mathrm{kg})$ and a higher concentration $(10 \mathrm{mg} / \mathrm{kg})$. CBN 1 dust was added to ETF-PBS to ascertain stable time frames in which the solution could be used for mouse exposures. Solutions were prepared and samples of the solutions were collected immediately after preparation, and then at 1, 2, 4, and $6 \mathrm{~h}$. Samples were immediately centrifuged, supernatants removed, and examined using an ICP-MS to quantitate total soluble element concentrations. The analysis indicated that leaving the dust samples in an ETF-PBS solution for up to six hours did not substantially change the distribution of elements in solution. At $6 \mathrm{~h}$, soluble element concentrations in supernatant began to increase, indicating that insoluble:soluble portions remained constant for $6 \mathrm{~h}$ in solution. We did not test for changes in speciation, but only total values of elemental metals. This additional quality control measure verified our dosing solution concentrations, potential for flux, and accounted for potential contamination from PBS or other steps in our preparation process. To control for contamination in this preparation process, no metal spatulas or any other metal items were used for weighing, storage, manipulation, or transport of dust samples.

\subsection{Animals}

Mice were obtained from Charles River Laboratories (headquartered in Wilmington, MA) and were acclimated for 7 days to the conditions of the treatment room (12-h light/dark cycle, $22 \pm 2{ }^{\circ} \mathrm{C}, 60-65 \%$ relative humidity) at the University of Nevada Las Vegas (UNLV) animal facilities, which are accredited by the Association for Assessment and Accreditation of Laboratory Animal Care International. The UNLV Institutional Animal Care and Use Committee approved all experiments. Mice were housed in ventilated polycarbonate shoebox cages with corncob bedding and were given unlimited access to food and water.

\subsection{Animal exposures}

To simulate the potential health impacts of a month of weekend exposures to geogenic dust from the NDRA, adult female B6C3F1 mice were exposed to CBN 1 dust samples with a median diameter of $4.39 \mu \mathrm{m}$ (Table 1 ) at $0,0.01,0.1,1.0,10$, or $100 \mathrm{mg} / \mathrm{kg}$ of body weight once weekly for four weeks. Each dose administered was adjusted to body weight. Therefore, based on a $20 \mathrm{~g}$ mouse, $20 \mu \mathrm{g}$ was administered to the lung via oropharyngeal aspiration. Mice in the $0 \mathrm{mg} / \mathrm{kg}$ group received PBS only and served as a vehicle control group. To ensure availability of tissue for toxicology assays, each dose group was comprised of 12 mice, housed six per cage. In addition, three separate groups of mice were used for a total of three replicates for each exposure. Samples for toxicity studies were collected from each group three days in a row. Fig. 1 depicts the basic arrangement for replicates and sample collection.

Mice were exposed by oropharyngeal aspiration using isoflurane as an anesthetic agent. The dose was based on current body weight of the mouse. An average volume of $10 \mu \mathrm{L}$ was administered to each mouse; however, based on individual body weight changes, this volume was adjusted to between 9 and $13 \mu \mathrm{L}$ per mouse. One day after the final dose was delivered, samples for toxicity studies were collected from animals euthanized by carbon dioxide asphyxiation. The following assays were performed to determine a profile of toxicological effects specific to NDRA geogenic dust from CBN 1.

\subsection{Body weight, organ weights, and immune organ cellularity}

Body weight was monitored weekly during the study and terminal body weights were collected for all animals the day of euthanasia. The brain, kidney, liver, lung, spleen, and thymus were removed and weighed. Weights were adjusted for terminal body weights to determine absolute and relative organ weights. Spleens and thymuses were suspended in complete medium (RPMI, 10\% fetal calf serum, 50 IU penicillin and $50 \mu \mathrm{g}$ streptomycin) and were aseptically processed into single-cell suspensions by gentle grinding between two sterile, frosted microscope slides. An aliquot of each spleen or thymus suspension was manually counted on a hemocytometer to determine the number of live cells (viability of cells for each organ was generally greater than 95\%). The total number of cells per spleen and thymus (cellularity), adjusted by the weight of each organ, was determined for each animal from Set B (see Fig. 1).

\subsection{Hematology, clinical chemistry, and blood metals}

For hematology and clinical chemistry endpoints, blood from anesthetized animals was collected into a microtainer tube containing EDTA, which kept the blood from coagulating or in a microtainer with no anticoagulant for serum collection. Once collected, samples were sent overnight to the Montana Veterinary Diagnostic Laboratory (MVDL) in Bozeman, MT, for hematology (whole EDTA blood) and clinical chemistry analysis (serum). Hematology parameters included: white blood cells (WBC; $10^{9} / \mathrm{L}$ ), red blood cells (RBC; $10^{9} / \mathrm{L}$ ), hemoglobin (HGB; g/dl), hematocrit (HCT; \%), mean corpuscular volume $(\mathrm{MCV} ; \mathrm{fl})$, mean corpuscular hemoglobin ( $\mathrm{MCH} ; \mathrm{pg})$, mean corpuscular hemoglobin concentration (MCHC; \%), red cell distribution (RDW; \%), platelet count $\left(10^{9} / \mathrm{L}\right)$, neutrophils $(\%)$, neutrophils $\left(10^{9} / \mathrm{L}\right)$, lymphocytes $(\%)$, lymphocytes $\left(10^{9} / \mathrm{L}\right)$, monocytes $(\%)$, monocytes $\left(10^{9} / \mathrm{L}\right)$, eosinophils (\%), eosinophils $\left(10^{9} / \mathrm{L}\right)$. Clinical chemistry parameters included: creatine phosphokinase (CPK; IU/I), aspartate aminotransferase/serum glutamic oxaloacetic transaminase (AST/SGOT; IU/I), alanine aminotransferase/serum glutamic pyruvate transaminase (ALT/SGPT; $\mathrm{IU} / \mathrm{I})$, alkaline phosphatase (ALKP; IU/I), glucose ( $\mathrm{mg} / \mathrm{dl})$, cholesterol $(\mathrm{mg} / \mathrm{dl})$, total protein $(\mathrm{g} / \mathrm{dl})$, albumin $(\mathrm{g} / \mathrm{dl})$, globulin $(\mathrm{g} / \mathrm{dl})$, phosphate $(\mathrm{mg} / \mathrm{dl})$, blood urea nitrogen $(\mathrm{BUN} ; \mathrm{mg} / \mathrm{dl})$, creatinine $(\mathrm{mg} / \mathrm{dl})$, and total bilirubin ( $\mathrm{mg} / \mathrm{dl}$ ). Hematologies were run on all samples; however clinical chemistries performed were dependent on the volume of 


\begin{tabular}{|c|c|c|}
\hline \multicolumn{3}{|c|}{$\begin{array}{l}12 \text { mice per dose, three replicates } \\
\text { Dose groups (mg/kg bw): } 0,0.01,0.1,1,10,100\end{array}$} \\
\hline $\begin{array}{c}\text { Replicate 1: } \\
\text { Set A: } 6 \text { mice/dose } \\
\text { Collect: blood, lungs and brains for } \\
\text { histology, and organ weights (brain, } \\
\text { kidney, liver, spleen, thymus) }\end{array}$ & $\begin{array}{c}\text { Replicate 2: } \\
\text { Set A: } 6 \text { mice/dose } \\
\text { Collect: blood, brains for histology, } \\
\text { and organ weights (brain, kidney, } \\
\text { liver, lungs, spleen, thymus) }\end{array}$ & $\begin{array}{c}\text { Replicate 3: } \\
\text { Set A: } 6 \text { mice/dose } \\
\text { Collect: blood and organs for } \\
\text { metal/metalloid analysis (brain, } \\
\text { kidney, liver, lungs, spleen, thymus) }\end{array}$ \\
\hline $\begin{array}{c}\text { Set B: } 6 \text { mice/dose } \\
\text { Collect: blood, lung weights, } \\
\text { immune organs (spleen and } \\
\text { thymus) }\end{array}$ & $\begin{array}{l}\text { Set B: } 6 \text { mice/dose } \\
\text { Collect: blood, immune organs } \\
\text { (spleen and thymus) }\end{array}$ & $\begin{array}{l}\text { Set B: } 6 \text { mice/dose } \\
\text { Collect: blood and immune organs } \\
\text { (spleen and thymus) }\end{array}$ \\
\hline
\end{tabular}

Fig. 1. Toxicology sample collection arrangement.

sample provided and not all samples were of sufficient volume. For this reason, hematology and clinical chemistry analyses were not performed in duplicate or triplicate as were other assays.

For determination of blood metal and metalloid concentrations, blood from anesthetized mice was collected into a microtainer tube containing heparin. Using an analytical balance, each blood collection tube was weighed before and after collection of blood to determine the weight of each blood sample. Once collected, samples were frozen at $-80{ }^{\circ} \mathrm{C}$ and then shipped to the Laboratory Services Bureau of the Montana Department of Public Health and Human Services for analysis of total levels of metal and metalloid concentrations. Metals/metalloids included: arsenic, cadmium, chromium, lead, magnesium, manganese, molybdenum, nickel, strontium, vanadium, and zinc. Blood metal/metalloid concentrations were not performed in duplicate or triplicate as were other assays. Due to limited volumes, whole blood values were determined only.

\subsection{Immunophenotyping of B lymphocytes and $C D 4 / C D 8$ lymphocytes}

The number of splenic B cells (B220) and splenic and thymic T cells $(\mathrm{CD} 4+, \mathrm{CD} 8+, \mathrm{CD} 4+/ \mathrm{CD} 8+$, and $\mathrm{CD} 4-/ \mathrm{CD} 8-)$ was counted in singlecell suspensions diluted to a concentration of $1 \times 10^{7}$ cells $/ \mathrm{mL}$. Optimal concentrations of flow antibodies and reagents were determined in previous experiments. All experimental replicates included isotype controls (to estimate non-specific binding), unstained cells as negative controls, and single color controls as positive controls to determine color compensation. Flow cytometric analysis was performed using a BD FACSCalibur flow cytometer (Becton-Dickinson, San Jose, CA, USA) and 10,000 events were collected from each sample. The total number of each cell type was determined from the spleen or thymus cellularity.

\subsection{Immunophenotyping of regulatory T lymphocytes (Tregs)}

Splenic lymphocytes were adjusted to a concentration of $1 \times 10^{6}$ cells per well and depleted of red blood cells via a 5-minute incubation in $\mathrm{NH}_{4} \mathrm{Cl}$ lysis buffer at $37^{\circ} \mathrm{C}$. Monoclonal antibodies coupled to fluorochromes specific for the following markers were used at a concentration of $1 \mu \mathrm{g} / 10^{6}$ cells: anti-mouse CD25-FITC, rat IgG1-PE isotype control, rat IgG2b-AF647 isotype control, and rat IgG2b-FITC isotype control (BD Pharmingen, San Diego, CA, USA). FoxP3, CD4, and IL-17 cells were stained using a commercial kit (BD Pharmingen, San Diego, CA, USA or eBiosciences, San Diego, CA, USA) according to manufacturer's instructions. Appropriate positive, negative, and isotype controls were added to wells containing cells only. Treg subsets were quantified using a BD FACSCalibur flow cytometer (Becton-Dickinson, San Jose, CA, USA). 10,000 events were acquired for each sample. CD4 + lymphocytes in the lymphocyte fraction were gated, and the percentages of $\mathrm{CD} 25^{+}$-

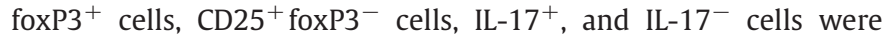
calculated.

\subsection{Plaque forming cell (PFC) assay}

The primary IgM response to sheep red blood cells (SRBC; Rockland, Gilbertsville, PA) was determined using a modified hemolytic plaque assay (Jerne and Nordin, 1963), which allows for an estimate of the number of B cells ("plaque forming cells" or "PFCs") producing antibody against SRBC. Five days before euthanasia, mice were given an intraperitoneal injection of $100 \mu \mathrm{L}$ of $25 \%$ SRBC in PBS. Single-cell suspensions (as previously described) were prepared from spleens of mice injected with SRBC and diluted to a concentration of $1.0 \times 10^{6}$ cells $/ \mathrm{mL}$. A $10 \mu \mathrm{L}$ aliquot of the single-cell suspension was added to a tube containing $100 \mu \mathrm{L}$ of $25 \%$ SRBC in PBS, $40 \mu \mathrm{L}$ of RPMI medium (without additives), and $50 \mu \mathrm{L}$ of guinea pig complement. Aliquots of the solution were placed into Cunningham chamber slides. The slides were sealed with paraffin and were incubated at $37{ }^{\circ} \mathrm{C}$ and $5 \% \mathrm{CO}_{2}$ for $1-2 \mathrm{~h}$. PFCs were counted microscopically and were reported as PFCs/million splenocytes.

\subsection{Natural killer cell activity}

Natural killer (NK) cell activity was assessed via an in vitro cytotoxicity assay using ${ }^{51} \mathrm{Cr}$-labeled Yac-1 cells as described previously (Duke et al., 1985; Holsapple et al., 1988). To minimize radioactive waste, the procedure was adapted to 96-well plates that were read on a Packard Top Count scintillation counter. Spleen single-cell suspensions were adjusted to $2 \times 10^{7}$ cells $/ \mathrm{mL}$ in complete medium and then the spleen cells and Yac- 1 cells were added, in triplicate wells, in ratios of 100:1, 50:1, 25:1, and 12.5:1 spleen cells:labeled Yac-1 cells, and in a final volume of $0.2 \mathrm{~mL}$ per well. Maximum release was determined by lysing ${ }^{51} \mathrm{Cr}$ labeled Yac- 1 cells with $0.1 \%$ Triton X-100 in complete medium. Spontaneous release was determined by incubating Yac- 1 cells only in complete medium. After a four hour incubation at $37{ }^{\circ} \mathrm{C}$ and $5 \% \mathrm{CO}_{2}$, the plates were centrifuged ( $1200 \mathrm{rpm}, 3 \mathrm{~min}$ ), and $25 \mu \mathrm{L}$ of supernatant was then transferred to a 96-well plate containing solid scintillant (LumaPlate). Plates were air dried overnight and within $24 \mathrm{~h}$, were counted for 5 min, after a 10-min dark delay, using a Packard Top Count-NXT. The results are expressed in lytic units per $10^{7}$ splenocytes using $10 \%$ lysis as the reference point as described by Bryant et al., 1992; equation 10. Essentially, this measure considers the target tumor cell activity in the context of both maximum and spontaneous release. This method has been validated in interlaboratory studies by the National Toxicology Program (Luster, et al., 1988).

\subsection{Neuronal autoantibody formation}

Blood was collected, held at room temperature for at least $30 \mathrm{~min}$, and then centrifuged at $4{ }^{\circ} \mathrm{C}$ to separate serum. Sera were then frozen at $-80{ }^{\circ} \mathrm{C}$ until analysis of IgM and IgG antibody concentrations. Flatbottom 96 -well high binding microtiter plates were coated with 
$100 \mu \mathrm{L}$ of $1 \mathrm{mg} / \mathrm{mL}$ of purified neuronal protein for either glial fibrillary acidic protein (GFAP; American Research Products, Waltham, MA), myelin basic protein (MBP; Sigma-Aldrich, St. Louis, MO), or neurofilament 68 (NF-68; American Research Products, Waltham, MA) and then incubated at $4{ }^{\circ} \mathrm{C}$ overnight (at least $16 \mathrm{~h}$ ). After washing, blocking of nonspecific binding, and addition of serum samples (serially diluted $1: 100$ ), secondary antibody (alkaline phosphatase goat anti-mouse IgM or IgG; ABCAM, Cambridge, MA) was added. Each set of two plates also included mouse monoclonal primary antibodies directed against each of the three neuronal proteins instead of serum samples; these primary antibodies were added in known concentrations and served as standard curves. All plates also included blank wells. Following washes and addition of substrate ( $p$-nitrophenyl-phosphate; Sigma-Aldrich, St. Louis, MO), plates were incubated for $30 \mathrm{~min}$ at room temperature and then stop solution ( $0.4 \mathrm{~N}$ sodium hydroxide) was added. Plates were read at $405 \mathrm{~nm}$ on a BioTek Synergy HT plate reader. Optical density values were converted to $\mathrm{ng} / \mathrm{mL}$ concentrations using values obtained from the standard curve. All sera were assayed twice to verify results. Values that fell below the limits of detection were assigned a value of zero. Values that fell above the limits of detection were diluted upon the second evaluation. Values that still remained above the limits of detection after dilution were eliminated from the overall calculations due to insufficient amounts of remaining sample for further analysis.

\subsection{Brain histology}

Immediately following euthanasia, the brains were removed, weighed, and immersion fixed in 10\% neutral buffered formalin. After $24 \mathrm{~h}$, the brains were transferred to $70 \%$ ethanol for storage at room temperature and were ultimately shipped to East Carolina University (ECU). Once received, the brains were processed and embedded by the Histology Laboratory Core in the Department of Anatomy and Cell Biology at ECU. Two sections of the cerebellum, each $10 \mu \mathrm{m}$ thick, were cut and mounted onto glass slides. One set of sections was stained with anti-CD3 + antibody (abcam, Cambridge, MA) and the other set was stained with anti-myelin basic protein (MBP) antibody (abcam, Cambridge, MA). In sections stained with anti-CD3 + , the number of $\mathrm{T}$ cells present throughout both sections was counted at $20 \times$ magnification. In sections stained with anti-MBP, the relative intensity of the stain was gauged relative to the intensity of the staining of the sections from the control brains. Control brains were scored as weak (1), mild (2), moderate (3), or strong (4). The intensity of the stain in the brains from exposed animals was assigned a numerical value according to the following scale: $0=$ no change in staining intensity relative to controls; 1 = very weak staining intensity relative to controls; $2=$ mild intensity in staining relative to controls; $3=$ moderate intensity in staining relative to controls; $4=$ strong intensity in staining relative to controls; $5=$ very strong intensity in staining relative to controls.

\subsection{Particle positive control}

To test "elemental metal effects" vs. "particle effects", separate groups of mice were exposed to titanium dioxide $\left(\mathrm{TiO}_{2}\right) \cdot \mathrm{TiO}_{2}$ is used often as a particle control as it is considered "neutral" with no associated heavy metals. It was approximately $21 \mathrm{~nm}$ in size and was administered to separate groups of mice via the same exposure paradigm as mice exposed to geogenic dust samples from $\mathrm{CBN} 1$. $\mathrm{TiO}_{2}$ was prepared in sterile, endotoxin-free, phosphate buffered saline (ETF-PBS) at concentrations of $0.01,0.1,1,10$, or $100 \mathrm{mg}$ of particle $/ \mathrm{kg}$ of body weight and was administered to mice within $1-2 \mathrm{~h}$ of preparation. Toxicity testing was evaluated in the $\mathrm{TiO}_{2}$ exposed mice in parallel with CBN 1 exposed mice.

\subsection{Statistical analysis}

Data were tested for normality and homogeneity and, if needed, appropriate transformations were made. A one-way analysis of variance (ANOVA) was used to determine differences among doses for each endpoint using JMP 9 (SAS Institute Inc., Cary, NC) in which the standard error used a pooled estimate of error variance. When significant differences were detected by the F-test ( $\mathrm{p}<0.05$ ), Dunnett's t-test was used to compare treatment groups to the $0 \mathrm{mg} / \mathrm{kg}$ group. A Dunnett's t-test also was used to compare results of the $0 \mathrm{mg} / \mathrm{kg}$ group to the $\mathrm{TiO}_{2}$ group.

\subsection{Quality assurance}

This study was conducted as under the conceptual guidance of Good Laboratory Practices (GLP). Within this guidance, periodic audits of all aspects of the project were conducted as well as extensive independent review of all documentation and data. In addition, each of the participating university sites conducting experiments (UNLV, MSU and ECU) were audited by an internal but independent Quality Assurance team. All final notebooks were reviewed and initialed by the Quality Assurance Team.

\section{Results}

\subsection{CBN 1 geogenic dust characterization}

Dust from CBN 1 used in this study had a median diameter of $4.39 \mu \mathrm{m}$ as determined by laser diffraction (Table 1 and Fig. 7). Total digestion chemical composition of the dust is also shown in Table 1. All of the arsenic was As (V) (Table 2).

\subsection{Body weight, organ weights, and immune organ cellularity}

Overall, mice in the dosed groups gained weight over the 28-day exposure and did not demonstrate significant, dose-related changes in body weight when compared to mice from the $0 \mathrm{mg} / \mathrm{kg}$ group. No significant changes in immune organ weights, thymic and splenic cellularities, kidney, lung, or brain weights, were observed. In two of the three replicates, relative liver weights were significantly decreased in mice exposed to $0.1,1,10$, or $100 \mathrm{mg} / \mathrm{kg}$ of geogenic dust. This decrease ranged from $6 \%-14 \%$ relative to the $0 \mathrm{mg} / \mathrm{kg}$ group and changes were not dose-responsive. No significant body weight or organ weight changes were observed in mice exposed to $\mathrm{TiO}_{2}$.

\subsection{Hematology, clinical chemistry, and blood metals}

Hematological endpoints measured in mice dosed with dust samples from CBN 1 did not vary statistically significantly relative to responses in the $0 \mathrm{mg} / \mathrm{kg}$ group nor were any changes dose-responsive in nature. Similarly, most clinical chemistry endpoints did not vary by dose; however, plasma creatinine was dose-responsively increased in mice exposed to $0.01 \mathrm{mg} / \mathrm{kg}$ to $100 \mathrm{mg} / \mathrm{kg}$ (Fig. 2). We did not measure these endpoints in $\mathrm{TiO}_{2}$ exposed mice due to limited blood volume available in this smaller subset of mice.

Table 2

Arsenic speciation of dry geogenic dust sample from CBN 1 .

\begin{tabular}{lllll}
\hline As $($ III $)$ & As $(\mathrm{V})$ & MMAs & DMAs & Units \\
\hline ND $(<0.27)$ & 21.4 & ND $(<0.20)$ & ND $(<0.18)$ & $\mu \mathrm{g} / \mathrm{g}$ \\
\hline
\end{tabular}

All results reflect the applied dilution.

All results reported as received (Wet Weight).

$\mathrm{ND}=$ Not detected at the applied dilution.

MMAs = Monomethylarsonic acid.

DMAs $=$ Dimethylarsinic acid 


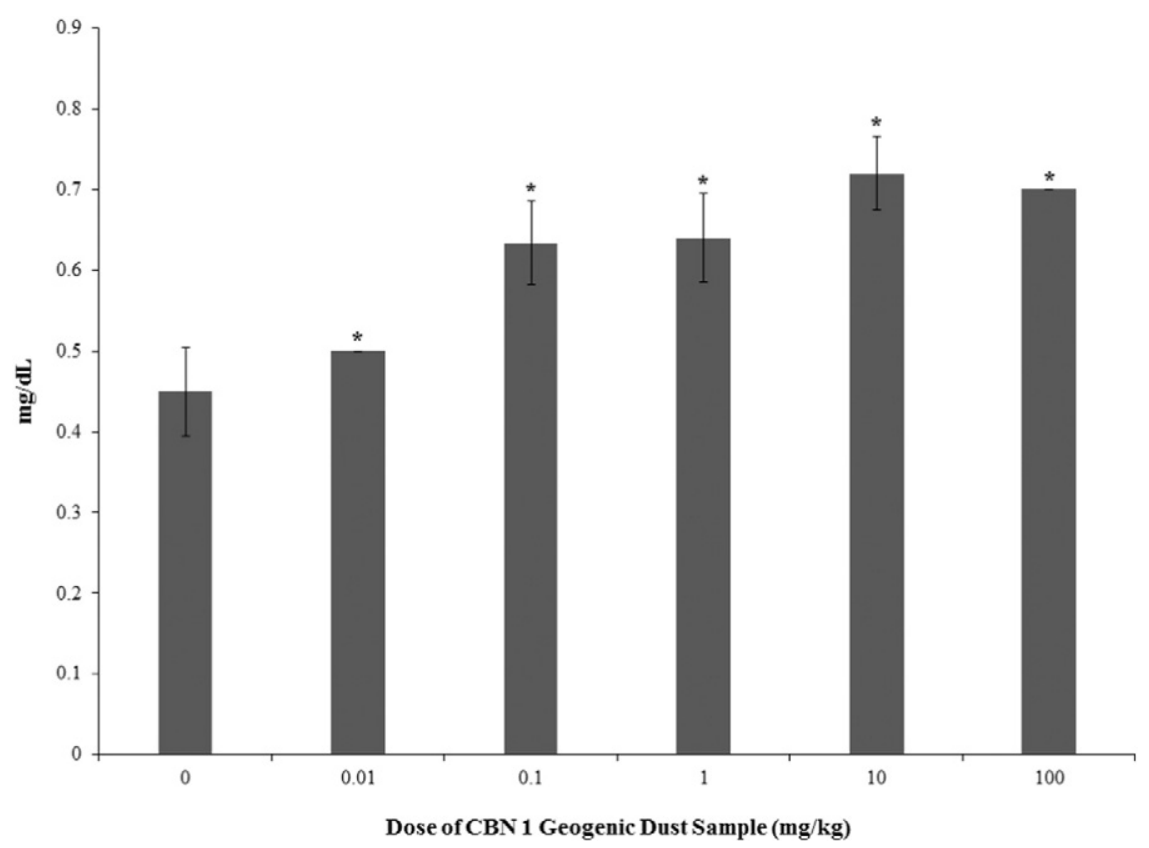

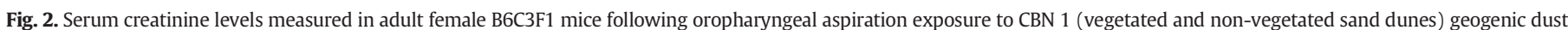

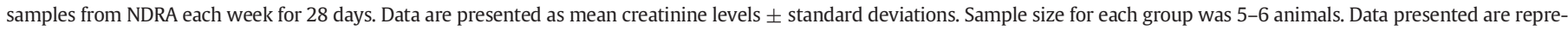
sentative of one trial day. The $\left({ }^{*}\right)$ indicates a response statistically different from the $0 \mathrm{mg} / \mathrm{kg}$ group $(\mathrm{p}<0.05)$.

Whole blood collected from mice $24 \mathrm{~h}$ after the final exposure had detectable concentrations of the metals/metalloids (Table 3). Mean concentrations did not differ by dose.

\subsection{Immunophenotyping}

The total number of splenic B cells and the total number of splenic and thymic T CD4/CD8 lymphocyte subpopulations did not statistically change by exposure to CBN 1 geogenic dust (Table 4). The number of $\mathrm{CD} 4{ }^{+} \mathrm{CD} 25^{+}$foxP3 ${ }^{-}$lymphocytes was statistically reduced at all administered doses (Table 4 ) by $88.4 \%$, on average, relative to the $0 \mathrm{mg} / \mathrm{kg}$ group. No statistically significant lymphocyte subpopulation changes were observed in mice exposed to $\mathrm{TiO}_{2}$.

\subsection{Plaque forming cell (PFC) assay}

Exposure to geogenic dust samples from CBN 1 significantly reduced the number of plaque forming cells secreting IgM antibody to SRBC at all administered doses (Fig. 3). PFC/million of spleen cells was reduced by $45-74 \%$ in dosed groups relative to the $0 \mathrm{mg} / \mathrm{kg}$ group. As even the lowest dose group was reduced relative to the $0 \mathrm{mg} / \mathrm{kg}$ group, a NOAEL

Table 3

Total elemental concentration ( $\mu \mathrm{g} / \mathrm{g}$ in wet sample) in whole blood of animals dosed with CBN 1 geogenic dust from vegetated and non-vegetated sand dunes from NDRA each week for 28 days.

\begin{tabular}{lllllll}
\hline & $0 \mathrm{mg} / \mathrm{kg}$ & $0.01 \mathrm{mg} / \mathrm{kg}$ & $0.1 \mathrm{mg} / \mathrm{kg}$ & $1 \mathrm{mg} / \mathrm{kg}$ & $10 \mathrm{mg} / \mathrm{kg}$ & $100 \mathrm{mg} / \mathrm{kg}$ \\
\hline $\mathrm{As}$ & 0.0050 & 0.0037 & 0.0063 & 0.0033 & 0.0040 & 0.0037 \\
$\mathrm{Cd}$ & $\mathrm{a}$ & $\mathrm{a}$ & $\mathrm{a}$ & $\mathrm{a}$ & 0.0077 & $\mathrm{a}$ \\
$\mathrm{Cr}$ & $\mathrm{a}$ & $\mathrm{a}$ & $\mathrm{a}$ & $\mathrm{a}$ & $\mathrm{a}$ & 0.0358 \\
$\mathrm{~Pb}$ & $\mathrm{a}$ & 0.0013 & 0.0018 & 0.0029 & 0.0016 & $\mathrm{a}$ \\
$\mathrm{Mg}$ & 36.9 & 35.9 & 45.5 & 35.2 & 35.2 & 35.7 \\
$\mathrm{Mn}$ & 0.0231 & 0.0202 & 0.0268 & 0.0206 & 0.0204 & 0.0218 \\
$\mathrm{Mo}$ & 0.0602 & 0.0929 & 0.0448 & 0.0571 & 0.0225 & 0.0430 \\
$\mathrm{Ni}$ & 0.0176 & 0.0366 & $\mathrm{a}$ & $\mathrm{a}$ & $\mathrm{a}$ & $\mathrm{a}$ \\
$\mathrm{Sr}$ & 0.0092 & 0.0074 & 0.0124 & 0.0084 & 0.0083 & 0.0084 \\
$\mathrm{~V}$ & 0.0108 & 0.0084 & 0.0135 & 0.0101 & 0.0106 & 0.0106 \\
$\mathrm{Zn}$ & 4.32 & 4.26 & 5.55 & 4.33 & 4.21 & 4.30 \\
\hline
\end{tabular}

a Indicates values not on the standard curve were not used. could not be determined. Therefore, the LOAEL was identified as $0.01 \mathrm{mg} / \mathrm{kg}$ for this response. No statistically significant changes in the PFC response were observed in mice exposed to $\mathrm{TiO}_{2}$.

\subsection{Natural killer cell activity}

Natural killer cell activity following exposure to geogenic dust samples from CBN1 (Fig. 4) did not change dose-responsively. Lytic activity of the 1.0 and $100 \mathrm{mg} / \mathrm{kg}$ exposure group was statistically increased relative to the activity of the $0 \mathrm{mg} / \mathrm{kg}$ group. No statistically significant changes were observed in mice exposed to $\mathrm{TiO}_{2}$.

\subsection{Neuronal autoantibody formation}

Exposure to geogenic dust from CBN 1 reduced IgM antibody production against NF-68 and GFAP and IgG antibody production against GFAP, relative to production in the $0 \mathrm{mg} / \mathrm{kg}$ group. NF-68 IgM in the $0.1-$ $100 \mathrm{mg} / \mathrm{kg}$ dosed groups (Fig. 5A) was reduced by $84 \%$, on average, and GFAP IgM in the $100 \mathrm{mg} / \mathrm{kg}$ dosed group (Fig. 5B) was reduced by $28.9 \%$ relative to the $0 \mathrm{mg} / \mathrm{kg}$ group. GFAP $\operatorname{lgG}$ in the 10 and $100 \mathrm{mg} / \mathrm{kg}$ dosed groups (Fig. 5C) was reduced by $42.2 \%$, on average, relative to the $0 \mathrm{mg} / \mathrm{kg}$ group. No other changes were statistically different.

\subsection{Brain histology}

The brains of animals exposed to geogenic dust from CBN 1 did not show $\mathrm{CD} 3+\mathrm{T}$ cell infiltration (data not shown). On average, MBP staining in the groups exposed to $0.1,10$, and $100 \mathrm{mg} / \mathrm{kg}$ was less intense relative to staining observed in the $0 \mathrm{mg} / \mathrm{kg}$ group (Fig. 6).

\section{Discussion}

Understanding health impacts of geogenic dust exposure is both a local and global concern (Kulshrestha et al., 2009; Aldabe et al., 2011; de Miranda et al., 2012; Wang et al., 2013). Yet, there is insufficient evidence to identify health effects of exposure to geogenic dust with different chemical compositions (Plumlee et al., 2006; Stanek et al., 2011). Further complicating this understanding is that dust in natural 
Table 4

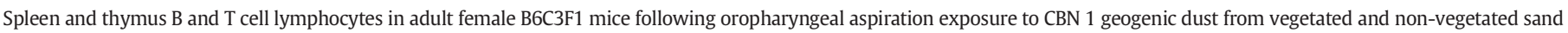
dunes from NDRA each week for 28 days.

\begin{tabular}{|c|c|c|c|c|c|}
\hline \multirow[t]{2}{*}{ Geogenic dust (mg/kg) } & \multicolumn{5}{|l|}{ Spleen } \\
\hline & $\begin{array}{l}\text { CD4+ } \\
\left(\text { cells } \times 10^{7}\right)\end{array}$ & $\begin{array}{l}\text { CD8 }+ \\
\left(\text { cells } \times 10^{7}\right)\end{array}$ & $\begin{array}{l}\mathrm{CD} 4+/ \mathrm{CD} 8+ \\
\left(\text { cells } \times 10^{6}\right)\end{array}$ & $\begin{array}{l}\text { CD4-/CD8- } \\
\left(\text { cells } \times 10^{8}\right)\end{array}$ & $\begin{array}{l}\text { B220 } \\
\left(\text { cells } \times 10^{7}\right)\end{array}$ \\
\hline 0 & $4.14 \pm 0.954$ & $1.48 \pm 0.158$ & $7.77 \pm 2.93$ & $1.08 \pm 0.282$ & $6.76 \pm 1.58$ \\
\hline 0.01 & $4.83 \pm 1.38$ & $1.91 \pm 0.543$ & $8.46 \pm 3.07$ & $1.28 \pm 0.267$ & $8.14 \pm 1.83$ \\
\hline 0.1 & $4.00 \pm 0.0554$ & $1.54 \pm 0.168$ & $5.53 \pm 3.03$ & $1.03 \pm 0.124$ & $6.45 \pm 0.867$ \\
\hline 1 & $3.64 \pm 0.0576$ & $1.38 \pm 0.166$ & $5.79 \pm 1.54$ & $0.917 \pm 0.144$ & $6.07 \pm 1.14$ \\
\hline 10 & $4.33 \pm 2.26$ & $1.53 \pm 0.757$ & $7.40 \pm 3.89$ & $1.17 \pm 0.583$ & $7.19 \pm 3.62$ \\
\hline 100 & $4.17 \pm 1.06$ & $1.60 \pm 0.415$ & $5.37 \pm 4.66$ & $1.14 \pm 0.156$ & $7.00 \pm 0.783$ \\
\hline \multirow[t]{2}{*}{ Geogenic dust (mg/kg) } & \multicolumn{5}{|l|}{ Thymus } \\
\hline & \multicolumn{2}{|l|}{$\begin{array}{l}\text { CD4+ } \\
\left(\text { cells } \times 10^{7}\right)\end{array}$} & $\begin{array}{l}\text { CD8 }+ \\
\left(\text { cells } \times 10^{6}\right)\end{array}$ & $\begin{array}{l}\mathrm{CD} 4+/ \mathrm{CD} 8+ \\
\left(\text { cells } \times 10^{7}\right)\end{array}$ & $\begin{array}{l}\text { CD4-/CD8- } \\
\left(\text { cells } \times 10^{6}\right)\end{array}$ \\
\hline 0 & \multicolumn{2}{|l|}{$1.19 \pm 0.255$} & $5.52 \pm 0.148$ & $8.17 \pm 2.29$ & $5.33 \pm 1.21$ \\
\hline 0.01 & \multicolumn{2}{|l|}{$1.23 \pm 0.256$} & $6.72 \pm 0.165$ & $9.09 \pm 1.57$ & $5.86 \pm 1.23$ \\
\hline 0.1 & \multicolumn{2}{|l|}{$0.949 \pm 0.275$} & $5.33 \pm 0.102$ & $7.73 \pm 3.03$ & $4.90 \pm 1.61$ \\
\hline 1 & \multicolumn{2}{|l|}{$1.21 \pm 0.335$} & $7.30 \pm 0.402$ & $7.88 \pm 2.70$ & $5.89 \pm 2.21$ \\
\hline 10 & \multicolumn{2}{|l|}{$1.09 \pm 0.280$} & $6.50 \pm 0.124$ & $8.42 \pm 1.53$ & $6.10 \pm 0.956$ \\
\hline 100 & \multicolumn{2}{|l|}{$1.15 \pm 0.383$} & $6.36 \pm 0.190$ & $9.06 \pm 2.95$ & $5.85 \pm 1.74$ \\
\hline \multirow[t]{2}{*}{ Geogenic dust (mg/kg) } & \multicolumn{5}{|l|}{ Spleen } \\
\hline & $\begin{array}{l}4+/ 25+/ \mathrm{fp} 3+ \\
\left(\text { cells } \times 10^{6}\right)\end{array}$ & $\begin{array}{l}4+/ 25-\mathrm{fp} 3+ \\
\left(\text { cells } \times 10^{7}\right)\end{array}$ & $\begin{array}{l}4+/ 25+/ \text { fp3- } \\
\left(\text { cells } \times 10^{6}\right)\end{array}$ & $\begin{array}{l}4+/ \text { IL17A+ } \\
\left(\text { cells } \times 10^{6}\right)\end{array}$ & $\begin{array}{l}4-/ \text { IL17A+ } \\
\left(\text { cells } \times 10^{6}\right)\end{array}$ \\
\hline 0 & $7.03 \pm 2.67$ & $1.09 \pm 0.458$ & $8.38 \pm 5.07$ & $0.993 \pm 0.388$ & $0.682 \pm 0.166$ \\
\hline 0.01 & $5.82 \pm 2.60$ & $1.33 \pm 0.417$ & $1.15 \pm 0.715^{*}$ & $0.979 \pm 0.522$ & $0.657 \pm 0.214$ \\
\hline 0.1 & $6.05 \pm 2.59$ & $1.18 \pm 0.573$ & $0.501 \pm 0.321^{*}$ & $0.851 \pm 0.375$ & $0.509 \pm 0.134$ \\
\hline 1 & $6.94 \pm 1.49$ & $1.35 \pm 0.366$ & $1.05 \pm 0.495^{*}$ & $1.00 \pm 0.277$ & $1.80 \pm 0.239$ \\
\hline 10 & $5.63 \pm 1.63$ & $1.09 \pm 0.403$ & $0.932 \pm 0.317^{*}$ & $0.905 \pm 0.236$ & $0.578 \pm 0.139$ \\
\hline 100 & $6.34 \pm 1.90$ & $1.21 \pm 0.360$ & $1.22 \pm 0.497^{*}$ & $1.05 \pm 0.324$ & $0.526 \pm$ \\
\hline
\end{tabular}

Data are presented as mean cell number \pm standard deviations. Sample size for each group was 5-6 animals. Data presented are representative of three trial days.

* indicates a response statistically different from the $0 \mathrm{mg} / \mathrm{kg}$ group $(\mathrm{p}<0.05)$ and was determined from log transformed data.

settings is often a complex mixture of mineral and components with highly variable chemical compositions and particle sizes ranging from nanometers to several tens of micrometers.

This study focused on sand dunes, the most popular sections for recreationists and the most emissive soil type of the NDRA. Human exposure to geogenic dust in the sand dune area is remarkable because these surfaces produce the greatest amount of respirable dust during wind erosion (Goossens et al., 2012). These surfaces also are highly emissive when driving an ORV up to $40 \mathrm{~km} / \mathrm{h}$. Mineral dusts are also commonly high in crystalline silica and aluminum, because they are

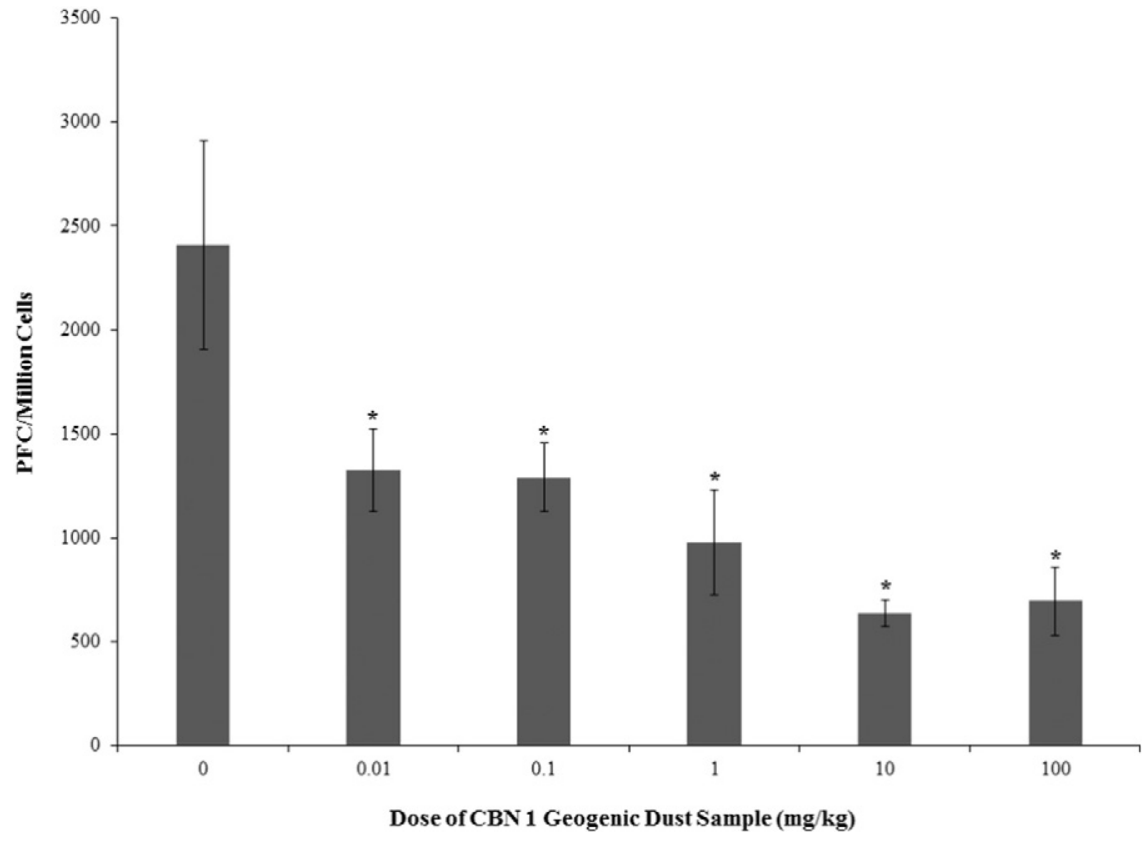

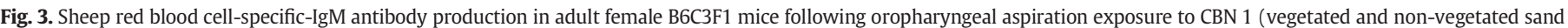

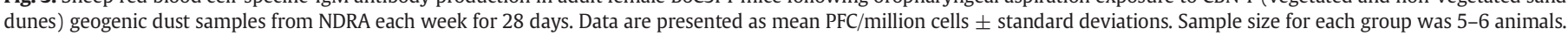

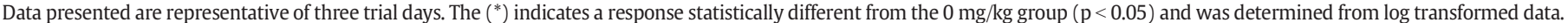




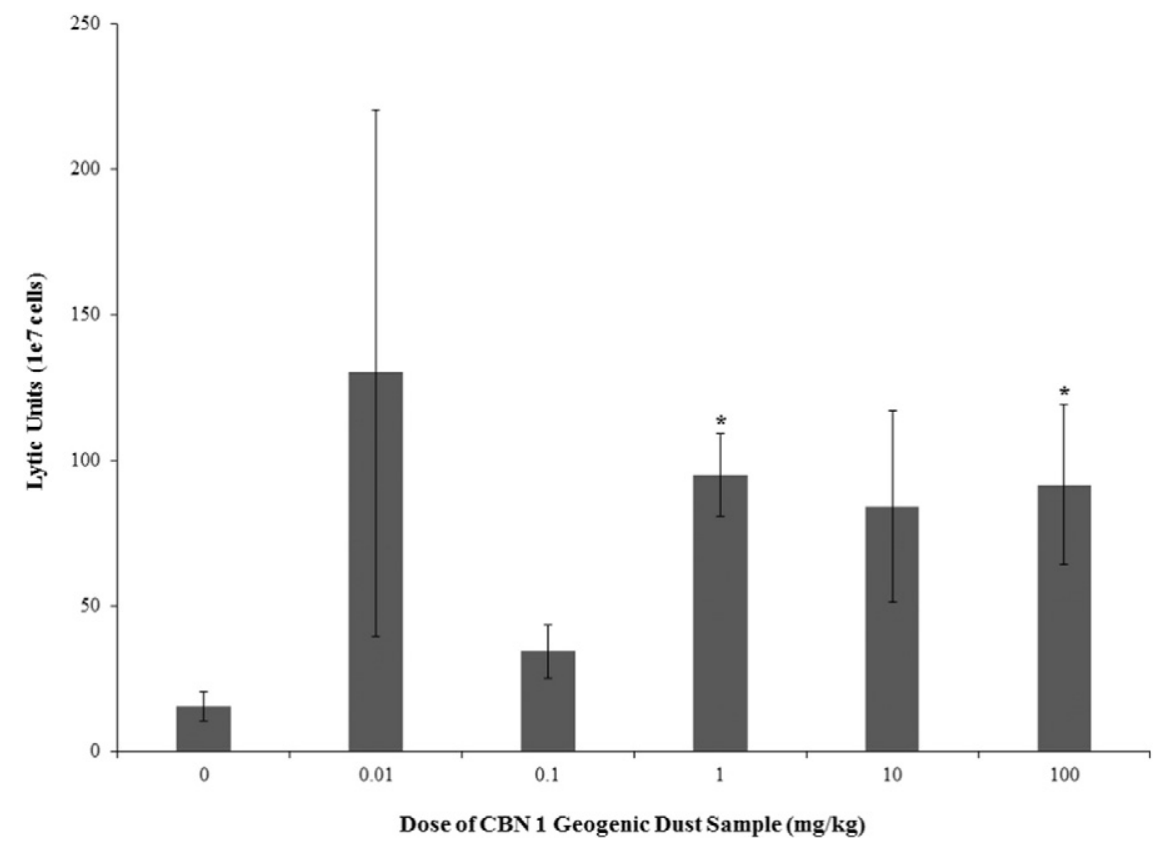

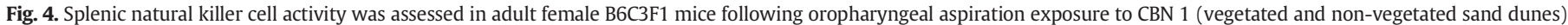

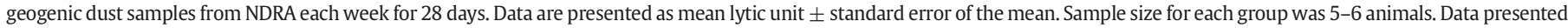
are representative of three trial days. The $\left({ }^{*}\right)$ indicates data significantly different from respective $0 \mathrm{mg} / \mathrm{kg}(\mathrm{p}<0.05)$ was determined from log transformed data.

primarily composed of common crustal aluminum silicate minerals. The concentration of metals and metalloids will vary based on geologic processes that can concentrate specific elements in rocks, and the chemical reactivity of the minerals and surface area of the particles themselves, which affects adsorption. In addition, airborne arsenic concentrations were of particular concern in this study due to its carcinogen classification (Anders et al., 2004; USEPA, 1988). Even though arsenic concentrations in the sand dune sediment are relatively low $(<10 \mu \mathrm{g} / \mathrm{g})$, on windy days, airborne arsenic concentrations can be quite high ( 0.01 to $>0.03 \mu \mathrm{g} / \mathrm{m}^{3}$ ). This poses concerns as a substantial amount of dust is emitted from the dunes, and because arsenic concentrations are greater in the finer-sized fractions (Goossens et al., 2015). During calm conditions, the airborne arsenic concentrations in the dunes are similar to background levels in rural areas elsewhere in the world, approximately $0.0004 \mu \mathrm{g} / \mathrm{m}^{3}$ (Suta, 1978; Ball et al., 1983).

The primary focus of this study was to define a range of health effects following geogenic dust exposure using a mouse model. A strength of this study is that we expanded the dose-response range to provide an opportunity to define a NOAEL and LOAEL. The selection of immunotoxicology parameters, PFC assay, NK cell assay, and flow cytometric evaluation of lymphocytic subpopulations, were included in this assessment due to their strength in predicting alterations in immune function (Luster et al., 1992; Luster et al., 1993; Keil et al., 1999; Keil et al., 2001). While a NOAEL could not be determined, the LOAEL established in this study was $0.01 \mathrm{mg} / \mathrm{kg}$ was based on both an immunological and kidney measure. A dose-responsive suppression of IgM antibody production and increasing levels of serum creatinine were the most sensitive parameters altered by exposure to geogenic dust from CBN 1. It is important to communicate that immunotoxicity occurred at geogenic dust concentrations corresponding with no overt toxicity defined as a $10 \%$ change in body weight from animals exposed to $0 \mathrm{mg} / \mathrm{kg}$. Greater than a $10 \%$ change in mouse body weight is an indicator of overt or systemic toxicity, often blurring direct effects on immune function. The LOAEL of $0.01 \mathrm{mg} / \mathrm{kg}$ was associated with a $45 \%$ reduction in IgM antibody production relative to the responses measured in the $0 \mathrm{mg} / \mathrm{kg}$ group. The large reduction in IgM antibody production at low concentrations of geogenic dust from CBN 1 indicates that this mixture is capable of interfering with the ability of $B$ cells to produce immune protective antibodies. A limitation of this study is that we did not have the budget to also measure organic compounds on the dust. Even though quantitated metals were notably high on the geogenic dust, we acknowledge the possibility of unmeasured organic compounds as an underlying part of the geogenic dust mixture that may also contribute to the effects reported in our model.

These observations are consistent with reports demonstrating that single exposures to lead, arsenic or crystalline silica suppress antibody responses. Specifically, arsenic and crystalline silica suppress the IgM response to T cell-dependent antigens, including SRBC and keyhole limpet hemocyanin (KLH) (Burchiel et al., 2009). Lead exposure suppressed serum levels of IgA, IgM and IgG and caused oxidative damage in Fischer 344 rats (Ercal et al., 2000). With regard to human studies, little is known about how metals-containing dusts affect serum antibody levels. Bencko and colleagues reported that workers exposed to arsenic in a coal-burning plant had reduced serum levels of IgM, IgA or IgG that were less than 1/10 the levels of matched controls (Bencko et al., 1988). Like the geogenic dusts used in these experiments, welding fumes vary with respect to the type and quantity of metals that they contain (Anderson et al., 2007). Anderson et al. (2007) evaluated the effects of stainless steel welding fumes that predominantly contain chromium and manganese. By oropharyngeal aspiration in mice, the highest administered concentration $(20 \mathrm{mg} / \mathrm{kg})$ suppressed the primary IgM antibody response to SRBCs without a concomitant reduction in the percentage of B or T cells (Anderson et al., 2007). An in vitro study in the same publication demonstrated that when splenic lymphocytes were exposed to either a soluble portion, an insoluble portion, or a mixture of the soluble and insoluble portion of the welding fume particles, only the soluble portion of the welding fume particles were capable of reducing primary antibody responses. As chromium and manganese were higher in the soluble fraction of welding fume particles than in the insoluble portion, Anderson et al. concluded that these metals were associated with the observed immune suppression (Anderson et al., 2007).

Although our environmental mixture was more complex, results of experiments with $\mathrm{TiO}_{2}$, a particle with no associated heavy metals, suggest that the metals and/or the minerals in the mixture, or the mixture of the metals and minerals with the particles, rather than the particles 


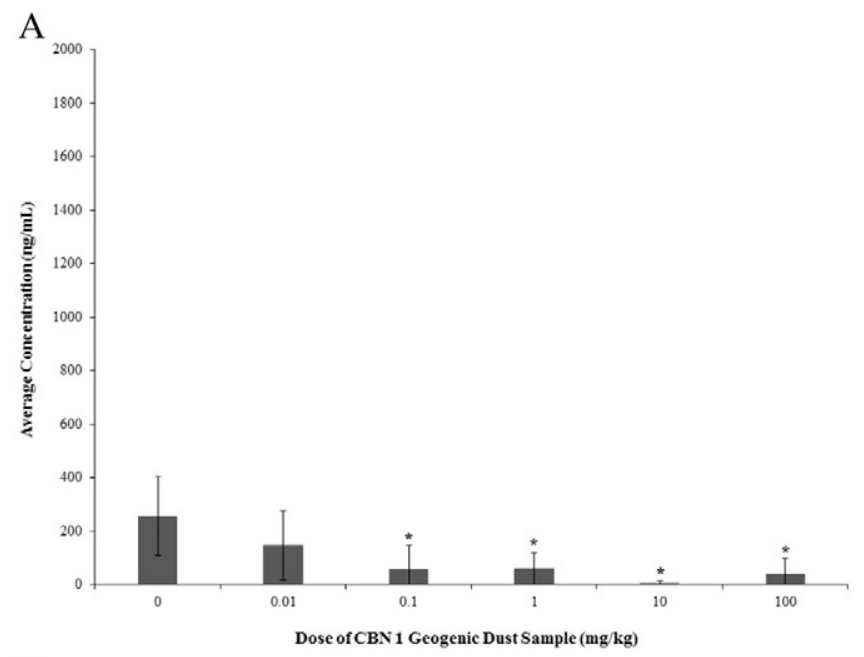

B

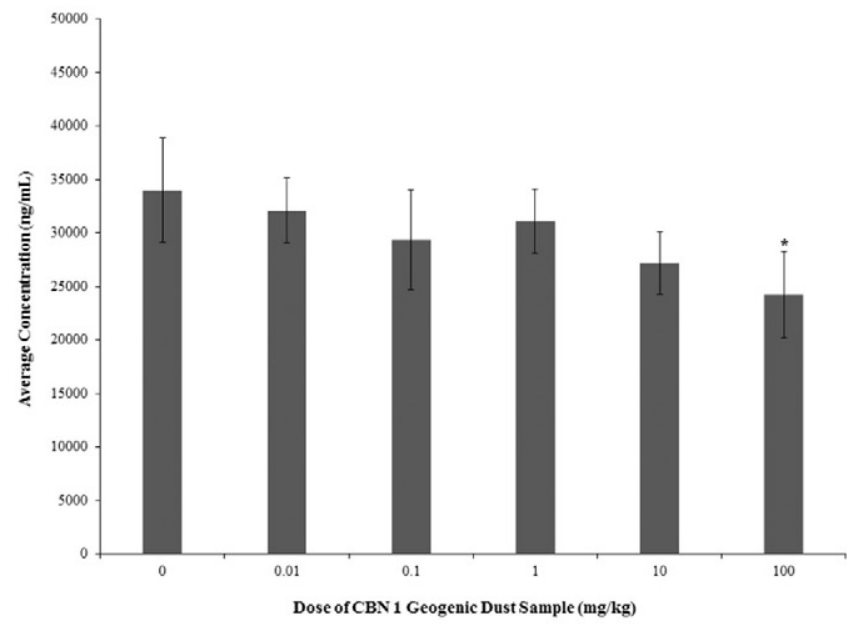

$\mathrm{C}$

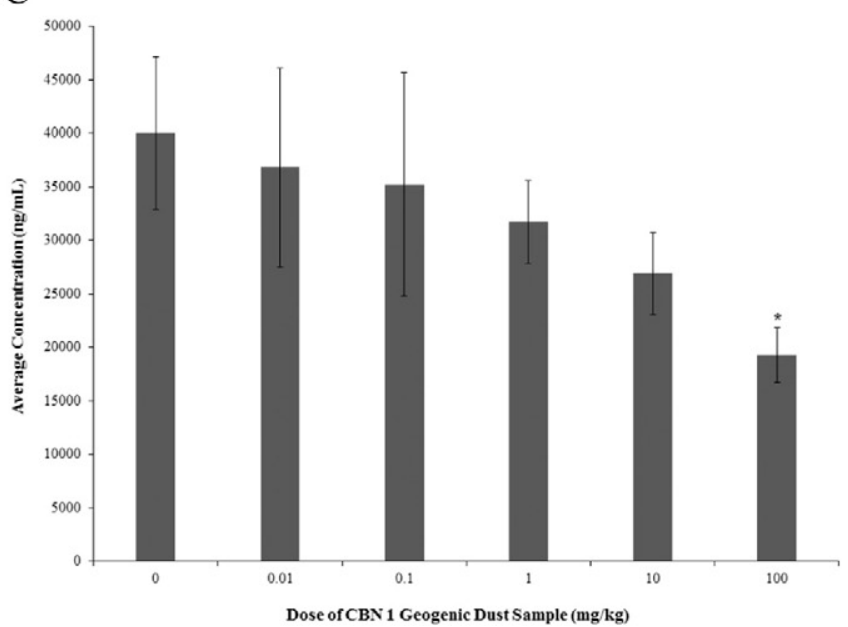

Fig. 5. Autoantibody production against neuronal proteins in adult female B6C3F1 mice following oropharyngeal aspiration exposure to CBN 1 (vegetated and non-vegetated sand dunes) geogenic dust samples from NDRA each week for 28 days. Data are presented as mean autoantibody levels \pm standard deviations. Sample size for each group was 5-6 animals. The $\left(^{*}\right)$ indicates a response statistically different from the $0 \mathrm{mg} / \mathrm{kg}$ group ( $\mathrm{p}<$ 0.05). A) NF-68 IgM; B) GFAP IgM; C) GFAP IgG.

alone, were likely contributing to the observed changes in immune function. Additionally, although each individual metal had a relatively low concentration in the blood (Table 3), we cannot discount that the cumulative concentration of the metals in the blood in combination with the particles may have produced the observed effects. Very little is known about environmental mixtures; this study is one of the first to evaluate such a complex mixture. In summary, at least five components in our geogenic dust, arsenic, lead, crystalline silica, chromium and manganese, are known to suppress IgM antibody production and this is consistent with our observations.

The average decrease in activated $\mathrm{T}$ helper cells $\left(\mathrm{CD} 4^{+} \mathrm{CD} 25^{+}\right.$foxP3 ${ }^{-}$) by approximately $88.4 \%$ in the exposure groups can account for reduced IgM antibody production. These lymphocytes are key to antigen presentation and subsequent antibody production (Vazquez et al., 2015). Of the elements in this complex geogenic dust mixture (Table 1), arsenic has been reported to reduce the CD4 + lymphocyte count (SotoPena et al., 2006), suppress proliferative lymphocytic responses, and decrease IL-2 production (Biswas et al., 2008). Crystalline silica exposures in an occupational environment led to workers with increased lymphoproliferative responses and decreased production of IL-2 (Rocha-Parise et al., 2014). IL-2 is key to activating T cells. Both silica and arsenic are reported to suppress this cytokine. Although this change to activated T helper cells was not reflected in the LOAEL established in this study, it is an important observation that may explain in part, the decreases in T cell-dependent IgM antibody production.

In some cases elevated levels of creatinine have been reported with exposure to inorganic arsenic (Moore et al., 1994). Furthermore, animal studies have reported that the urinary system is a more sensitive target for DMA than for MMA (Cohen et al., 2001). Evidently, our study differs in that we examined an exposure to silica and metals, arsenic included. In our mixture, dose-responsive increases in serum creatinine were observed following exposure to geogenic dust from CBN 1, comprising of $62 \mu \mathrm{g} / \mathrm{g}$ arsenic, $25 \mu \mathrm{g} / \mathrm{g}$ lead, $511 \mu \mathrm{g} / \mathrm{g}$ manganese, and $4.7 \mu \mathrm{g} / \mathrm{g}$ uranium (Table 1). Serum creatinine is a marker of kidney function and increasing levels suggest nephrotoxicity. Increased creatinine levels in the blood may also suggest diseases or conditions that affect kidney function such as acute tubular necrosis or glomerulonephritis from infection or autoimmune disease. The kidneys are particularly susceptible not only to metal toxicity, but also to silica. Silica exposure is associated with excess mortality from acute renal disease and an increased risk of end-stage renal disease (reviewed by Ghahramani, 2010). Therefore, it is plausible that the combined metals and silica exposure in our geogenic dust would alter a kidney function. It is important to remark that the increase in creatinine developed during 'weekend' exposures over one month. This is a swift change in creatinine and suggests diminished kidney function. Therefore, examination of chronic exposure to geogenic dust may be needed to understand the full extent of effects on the kidney.

Although our results indicate that Tregs were not depleted following an exposure to geogenic dust from CBN 1, previous research reported that arsenic or silica has been shown to affect immune regulation by specifically targeting Tregs. Tregs are recognized as a specialized subset of T lymphocytes responsible for suppression of immune responses and a key cell in preventing autoimmune disease. Silica exposure is associated with a variety of autoimmune problems, including rheumatoid arthritis, lupus, scleroderma, and glomerulonephritis (Lim et al., 2012). Tregs are characterized by high surface expression of CD25 (the IL-2 receptor alpha chain) and intracellular expression of the master switch transcription factor forkhead box protein P3 (FoxP3) (Fontenot et al., 2003). Studies have reported both increases and decreases in Treg populations following arsenic exposure (Hernandez-Castro et al. 2009; Thomas-Schoemann et al., 2012). This contrasts our studies where no change in numbers was observed. At this time, the reasons for this difference are unclear.

Upon injury to cells within the nervous system, liberated proteins may induce an autoimmune response measurable as serum autoantibodies (El-Fawal et al., 1999). El-Fawal and O'Callaghan reported increases in IgM and IgG antibodies against neural and glial proteins in rats exposed to only one dose of trimethyltin that were detectable up to three weeks post-exposure (El-Fawal and O'Callaghan, 2008), so this endpoint was chosen to evaluate the potential neurotoxicity of 


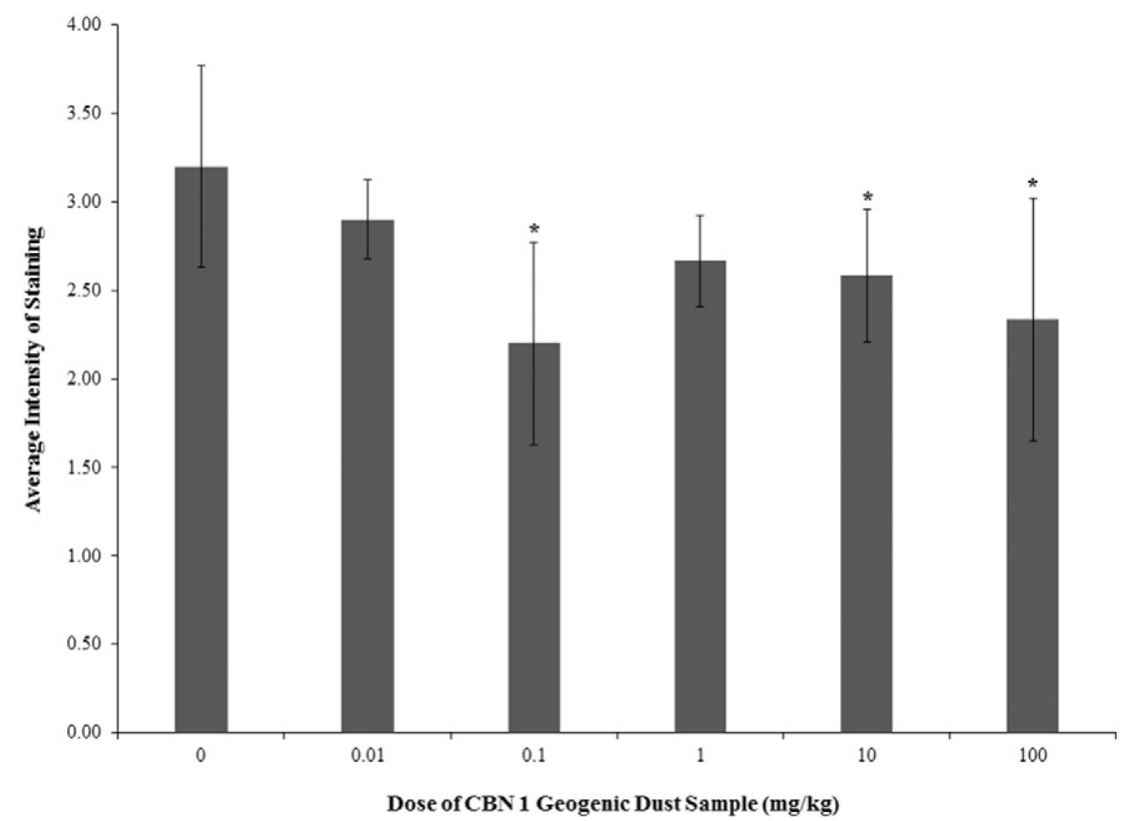

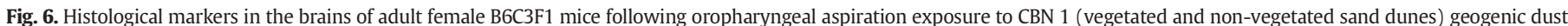

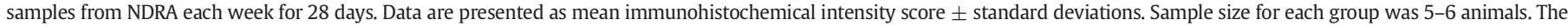
$\left({ }^{*}\right)$ indicates a response statistically different from the $0 \mathrm{mg} / \mathrm{kg}$ group $(\mathrm{p}<0.05)$.

the complex geogenic dust in this study. While statistically significant changes in autoantibodies against neural proteins were observed, they were reduced in animals from dosed groups, rather than increased relative to levels in the $0 \mathrm{mg} / \mathrm{kg}$ group. This is likely indicative of the overwhelming immune suppression observed in the PFC assay. Additionally, no infiltration of T cells was observed in the brains of dosed mice, which suggests that the geogenic dust from CBN 1 was not given at a concentration or for a duration sufficient to induce a strong enough inflammatory response to attract $\mathrm{T}$ cells from the periphery. The relative intensity of MBP was evaluated in brain sections to determine if autoantibodies or inflammatory processes were directed against this common brain protein that often is a target in neurodegeneration. The observed decrease in MBP in dosed groups $(0.1,10$, and $100 \mathrm{mg} / \mathrm{kg}$ ) relative to the control group can indicate inflammation-induced demyelination, which was detectable with immunohistochemistry, but not sufficient to attract immune cells from outside of the central nervous system. Additionally, the inconsistency and variability in this particular response indicate that the exposure paradigm or concentrations were not sufficient to induce strong reductions in MBP. While neurotoxicity cannot be ruled out as a concern, under the conditions of this study, overt neurotoxicity was not evident.

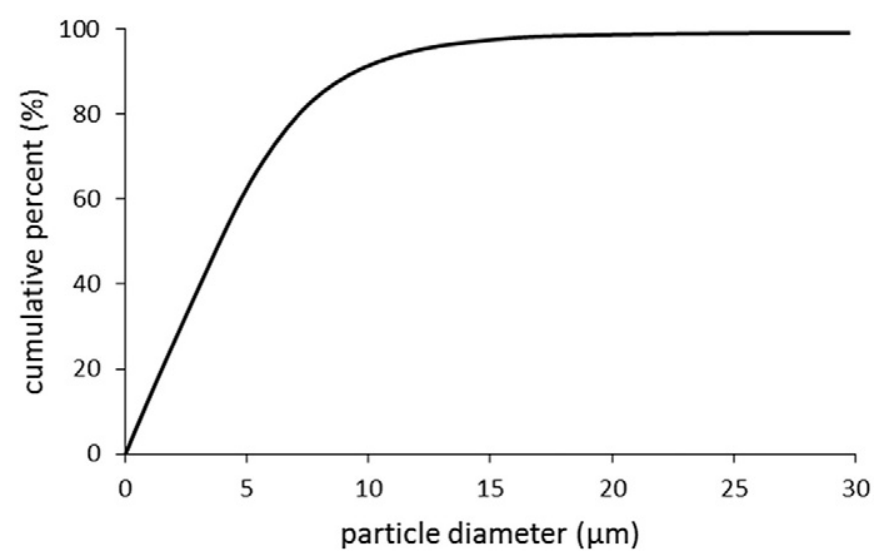

Fig. 7. Particle size distribution of the CBN1 geogenic dust used in this study.
The authors acknowledge that exposure and bioavailability of the adsorbed components in this geogenic dust are fundamental to bridging these data to human health risk. The complex interactions in the human body upon exposure to these substances are further complicated by the different bioaccessibility, biodurability, and bioreactivity of these minerals and their adsorbed components (Plumlee et al., 2006; Morman and Plumlee, 2013). In addressing this topic more completely, forthcoming publications from this research team will report on the bioaccessibility in fluids and bioavailability of the geogenic dust components in both mice and humans.

In conclusion, exposure to geogenic dust from sand dunes of the NDRA dose-responsively and consistently reduced the ability of the immune system to produce IgM antibodies against a T cell-dependent antigen with corresponding decreases in activated $\mathrm{T}$ helper cell populations. Based on the IgM antibody response data, the LOAEL established in this study was $0.01 \mathrm{mg} / \mathrm{kg}$, while a NOAEL could not be determined. The LOAEL was based on a dose-responsive immunological effect and a kidney measure. The immunological parameters affected in this study are known to be predictive of increased disease susceptibility (Luster et al., 1992; Luster et al., 1993) and, therefore, are regarded as reliable markers for immunotoxicity. Based on the lack of statistical findings with a "neutral particle" $\left(\mathrm{TiO}_{2}\right)$, our results suggest that the metal/mineral components associated with the geogenic dust in CBN 1 are likely to contribute to the reduction in antigen-specific antibody production. Suppression of this type of immune function is a sensitive indicator of immunotoxicity in experimental animal systems and is suggestive of the risk of immunotoxicity in other exposed organisms, including humans.

\section{Transparency document}

The Transparency document associated with this article can be found, in the online version.

\section{Acknowledgments}

This project was funded by the U.S. Bureau of Land Management (URL: http://www.blm.gov/nv/st/en/fo/lvfo.html), Grant number: L11AC20058. The funders had no role in study design, data collection 
and analysis, decision to publish, or preparation of the manuscript. We are grateful for the assistance of Margie Peden-Adams, Ph.D., Sharon Young, Ph.D., Qing Hu, Corey Boles, Hakan Gürleyük, Ph.D., Deborah Ellis, Ph.D., Henry LeTang, MLT(ASCP) and our grant legal consultant, Curtis Coulter.

\section{References}

Albright, J.F., Goldstein, R.A., 1996. Airborne pollutants and the immune system. Otolaryngol. Head Neck Surg. 114 (2), 232-238.

Aldabe, J., Elustondo, D., SantamarÃa, C., Lasheras, E., Pandolfi, M., Alastuey, A., Querol, X SantamarÃa, J.M., 2011. Chemical characterisation and source apportionment of PM2.5 and PM10 at rural, urban and traffic sites in Navarra (North of Spain). Atmospheric Research 102, 191-205.

Anders, W.M., Bull, R.J., Cantor, K.P., Chakraborti, D., Chen, C., DeAngelo, A.B., DeMarini, D.M., Ferreccio, C., Fukushima, S., Gebel, T.W., 2004. Some drinking-water disinfectants and contaminants, including arsenic. World Health Organization.

Anderson, S.E., Meade, B.J., Butterworth, L.F., Munson, A.E., 2007. The humoral immune response of mice exposed to manual metal arc stainless steel-welding fumes. J. Immunotoxicol. 4, 15-23.

Ball, A.L., Rom, W.N., Glenne, B., 1983. Arsenic distribution in soils surrounding the Utah copper smelter. Am. Ind. Hyg. Assoc. J. 44, 341-348.

Beelen, R., Hoek, G., van den Brandt, P.A., Goldbohm, R.A., Fischer, P., Schouten, L.J., Armstrong, B., Brunekreef, B., 2008. Long-term exposure to traffic-related air pollution and lung cancer risk. Epidemiology 19, 702-710.

Bencko, V., Wagner, V., Wagnerova, M., Batora, J., 1988. Immunological profiles in workers of a power plant burning coal rich in arsenic content. J Hyg Epidemiol Microbio Immunol 32, 137-146.

Biswas, R., Ghosh, P., Banerjee, N., Das, J.K., Sau, T., Banerjee, A., Roy, S., Ganguly, S. Chatterjee, M., Mukherjee, A., Giri, A.K., 2008. Analysis of T-cell proliferation and cytokine secretion in the individuals exposed to arsenic. Hum Exp Toxicol 27, 381-386.

Brauer, M., Hoek, G., Van Vliet, P., Meliefste, K., Fischer, P.H., Wijga, A., Koopman, L.P. Neijens, H.J., Gerritsen, J., Kerkhof, M., Heinrich, J., Bellander, T., Brunekreef, B. 2002. Air pollution from traffic and the development of respiratory infections and asthmatic and allergic symptoms in children. Am. J. Respir. Crit. Care Med. 166, 1092-1098.

Briggs, P.H., Meier, A.L., 1999. The Determination of Forty Two Elements in Geological Materials by Inductively Coupled Plasma-Mass Spectrometry. US Department of the Interior, US Geological Survey.

Bryant, J., Day, R., Whiteside, T.L., Herberman, R.B., 1992. Calculation of lytic units for the expression of cell-mediated cytotoxicity. J. Immunol. Methods 146, 91-103.

Buck, B.J., Goossens, D., Metcalf, R.V., McLaurin, B., Ren, M., Freudenberger, F., 2013. Naturally occurring asbestos: potential for human exposure, Southern Nevada, USA. Soil Sci. Soc. Am. J. 77, 2192-2204.

Burchiel, S.W., Mitchell, L.A., Lauer, F.T., Sun, X., McDonald, J.D., Hudson, L.G., Liu, K.J., 2009. Immunotoxicity and biodistribution analysis of arsenic trioxide in C57Bl/6 mice following a 2-week inhalation exposure. Toxicol. Appl. Pharmacol. 241, 253-259.

Calderón-Garcidueñas, L., Solt, A.C., Henríquez-Roldán, C., Torres-Jardón, R., Nuse, B. Herritt, L., Villarreal-Calderón, R., et al., 2008. Long-term air pollution exposure is associated with neuroinflammation, an altered innate immune response, disruption of the blood-brain barrier, ultrafine particulate deposition, and accumulation of amyloid $\beta-42$ and $\alpha$-synuclein in children and young adults. Toxicologic Pathology 36 (2), 289-310

Cohen, S.M., Yamamoto, S., Cano, M., Arnold, L.L., 2001. Urothelial cytotoxicity and regeneration induced by dimethylarsinic acid in rats. Toxicol. Sci. 59, 68-74.

de Miranda, R.M., de Fatima Andrade, M., Fornaro, A., Astolfo, R., de Andre, P.A., Saldiva, P., 2012. Urban air pollution: a representative survey of PM(2.5) mass concentrations in six Brazilian cities. Air Qual Atmos Health 5, 63-77.

Derbyshire, E., 2007. Natural minerogenic dust and human health. Ambio 36, 73-77.

Dockery, D.W., Pope 3rd, C.A., Xu, X., Spengler, J.D., Ware, J.H., Fay, M.E., Ferris Jr., B.G. Speizer, F.E., 1993. An association between air pollution and mortality in six U.S. cities. N Engl J Med 329, 1753-1759.

Dockery, D.W., Pope, C., 1994. Acute respiratory effects of particulate air pollution. Annu. Rev. Public Health 15, 107-132.

Duke, S.S., Schook, L.B., Holsapple, M.P., 1985. Effects of N-nitrosodimethylamine on tumor susceptibility. J. Leukoc. Biol. 37, 383-394.

El-Fawal, H.A., O'Callaghan, J.P., 2008. Autoantibodies to neurotypic and gliotypic proteins as biomarkers of neurotoxicity: assessment of trimethyltin (TMT). Neurotoxicology 29, 109-115.

El-Fawal, H.A., Waterman, S.J., De Feo, A., Shamy, M.Y., 1999. Neuroimmunotoxicology: humoral assessment of neurotoxicity and autoimmune mechanisms. Environ Health Perspect 107 (Suppl. 5), 767-775.

Ercal, N., Neal, R., Treeratphan, P., Lutz, P.M., Hammond, T.C., Dennery, P.A, Spitz, D.R. 2000. A role for oxidative stress in suppressing serum immunoglobulin levels in lead-exposed Fisher 344 rats. Arch. Environ. Contam. Toxicol. 39, 251-256.

Fontenot, J.D., Gavin, M.A., Rudensky, A.Y., 2003. Foxp3 programs the development and function of $\mathrm{CD}^{+}{ }^{+} \mathrm{CD} 25^{+}$regulatory T cells. Nat. Immunol. 4, 330-336.

Franklin, M., Koutrakis, P., Schwartz, P., 2008. The role of particle composition on the association between PM2.5 and mortality. Epidemiology 19, 680-689.

Ghahramani, N., 2010. Silica nephropathy. The International Journal of Occupational and Environmental Medicine 1 (3 July).
Gilmour, M.I., Koren, H., 2000. Interaction of inhaled particles with the immune system. In: Gehr, P.H. (Ed.), Particle-lung interactions. Marcel Dekker, New York, pp. 629-652.

Goossens, D., 2012. A method for dry extracting large volumes of fine particulate matter from bulk soil samples. Air Qual. Atmos. Health 5, 425-431.

Goossens, D., Buck, B., 2009. Dust emission by off-road driving: experiments on 17 arid soil types, Nevada, USA. Geomorphology 107, 118-138.

Goossens, D., Buck, B.J., McLaurin, B., 2012. Contributions to atmospheric dust production of natural and anthropogenic emissions in a recreational area designated for off-road vehicular activity (Nellis Dunes, Nevada, USA). J. Arid Environ. 78, 80-99.

Goossens, D., Buck, B., Teng, Y., McLaurin, B., 2015. Surface and airborne arsenic concentrations in a recreational site near Las Vegas, Nevada, USA. PLoS One 10 (4), e0124271. http://dx.doi.org/10.1371/journal.pone.0124271.

Hassani, M., Brown, J.M., Morandi, M.T., Holian, A., 2004. Particulate matter immunomodulatory effects on autoantibody development in New Zealand mixed mice. J. Immunotoxicol. 1 (2), 95-102.

Hernandez-Castro, B., Doniz-Padilla, L.M., Salgado-Bustamante, M., Rocha, D., Ortiz-Perez, M.D., Jimenez-Capdeville, M.E., Portales-Perez, D.P., Quintanar-Stephano, A., Gonzalez-Amaro, R., 2009. Effect of arsenic on regulatory T cells. J. Clin. Immunol. 29, 461-469

Holsapple, M.P., White Jr., K.L., McCay, J.A., Bradley, S.G., Munson, A.E., 1988. An immunotoxicological evaluation of 4,4'-thiobis-(6-t-butyl-m-cresol) in female B6C3F1 mice. 2. Humoral and cell-mediated immunity, macrophage function, and host resistance. Fundam Appl Toxicol 10, 701-716

Jerne, N.K., Nordin, A.A., 1963. Plaque formation in agar by single antibody-producing cells. Science 140,405

Keil, D.E., Luebke, R.W., Ensley, M., Gerard, P., Pruett, S.B., 1999. Evaluation of multivariate statistical methods for analysis and modeling of immunotoxicology data. Toxicol. Sci. $51,245-258$.

Keil, D.E., Leubke, R.W., Pruett, S.B., 2001. Quantifying the relationship between immunological parameters and host resistance. J. Immunol. 167, 4543-4552.

Kubachka, K.M., Shockey, N.V., Hanley, T.A., Conklin, S.D., Heitkemper, D.T., 2012. FDA Elemental Analysis Manual: Section 4.11: Arsenic Speciation in Rice and Rice Products Using High Performance Liquid Chromatography-Inductively Coupled Plasma-Mass Spectrometric Determination" Version 1.1. (http://www.fda.gov/Food/ FoodScienceResearch/LaboratoryMethods/ucm328363.htm).

Kulshrestha, A., Satsangi, P.G., Masih, J., Taneja, A., 2009. Metal concentration of PM2.5 and PM10 particles and seasonal variations in urban and rural environment of Agra, India. Sci Total Environ 407, 6196-6204.

Lambert, A.L., Trasti, F.S., Mangum, J.B., Everitt, J.I., 2003. Effect of preexposure to ultrafine carbon black on respiratory syncytial virus infection in mice. Toxicol. Sci. 72 (2), 331-338.

Lee, S.C., Cheng, Y., Ho, K.F., Cao, J.J., Louie, P.K.K., Chow, J.C., Watson, J.G., 2006. PM1.0 and PM2.5 Characteristics in the Roadside Environment of Hong Kong. Aerosol Science and Technology 40, 157-165.

Leonardi, G.S., Houthuijs, D., Steerenberg, P.A., Fletcher, T., Armstrong, B., Antova, T., Lochman, I., Lochmanova, A., Rudnai, P., Erdei, E., Musial, J., Jazwiec-Kanyion, B, Niciu, E.M., Durbaca, S., Fabianova, E., Koppova, K., Lebret, E., Brunekreef, B., van Loveren, H., 2000. Immune biomarkers in relation to exposure to particulate matter: a crosssectional survey in 17 cities of Central Europe. Inhal. Toxicol. 12 (Suppl. 4), 1-14.

Lim, S.S., Agan, M., Drenkard, C.M., 2012. Impact of systemic lupus erythematosus organ damage on unemployment or disability from a population-based cohort. Arthritis Research \& Therapy 14 (3), 1-28.

Linse, S., Cabaleiro-Lago, C., Xue, W.F., Lynch, I., Lindman, S., Thulin, E., et al., 2007. Nucleation of protein fibrillation by nanoparticles. Proc. Natl. Acad. Sci. U. S. A. 104, 8691-8696.

Luster, M.I., Munson, A.E., Thomas, P.T., Holsapple, M.P., Fenters, J.D., White, K.L., ... Dean, J.H., 1988. Development of a testing battery to assess chemical-induced immunotoxicity: National Toxicology Program's guidelines for immunotoxicity evaluation in mice. Toxicol. Sci. 10 (1), 2-19.

Luster, M.I., Portier, C., Pait, D.G., Rosenthal, G.J., Germolec, D.R., Corsini, E., Blaylock, B.L., Pollock, P. Kouchi, Y. Craig, W., et al., 1993. Risk assessment in immunotoxicology. II. Relationships between immune and host resistance tests. Fundam Appl Toxicol 21, 71-82.

Luster, M.I., Portier, C., Pait, D.G., White Jr., K.L., Gennings, C., Munson, A.E. Rosenthal, G.J., 1992. Risk assessment in immunotoxicology. I. Sensitivity and predictability of immune tests. Fundam Appl Toxicol 18, 200-210.

McLaurin, B.T., Goossens, D., Buck, B.J., 2011. Combining surface mapping and process data to assess, predict, and manage dust emissions from natural and disturbed land surfaces. Geosphere 7, 260-275.

Moore, M.M., Harrington-Brock, K., Doerr, C.L., 1994. Genotoxicity of arsenic and its methylated metabolites. Environ. Geochem. Health 16, 191-198.

Morman, S.A., Garrison, V.H., Plumlee, G.S., Lowers, H.A., Bunnell, J.E., 2009. Assessing concentration and bioaccessibly of potentially toxic elements in African dust. Geological Society of America Annual Meeting, p. 544 Portland, Oregon.

Morman, S.A., Plumlee, G.S., 2013. The role of airborne mineral dusts in human disease. Aeolian Res. 9, 203-212.

National Research Council. 2004. accessed 06-01-2015. http://epa.gov/ncer/science/pm/ 2008sab/exec_summary_2004_nrc_report.pdf.

Oberdorster, G., Sharp, Z., Atudorei, V., Elder, A., Gelein, R., Kreyling, W., Cox, C., 2004. Translocation of inhaled ultrafine particles to the brain. Inhal. Toxicol. 16, 437-445.

Plumlee, G.S., Morman, S.A., Ziegler, T.L., 2006. The toxicological geochemistry of earth materials: an overview of processes and the interdisciplinary methods used to understand them. Rev. Mineral. Geochem. 64, 5-57.

Pope 3rd, C.A., Thun, M.J., Namboodiri, M.M., Dockery, D.W., Evans, J.S., Speizer, F.E., Heath Jr., C.W., 1995. Particulate air pollution as a predictor of mortality in a prospective study of U.S. adults. Am J Respir Crit Care Med 151, 669-674. 
Rocha-Parise, M., Santos, L.M., Damoiseaux, J.G., Bagatin, E., Lido, A.V., Torello, C.O., ... Queiroz, M.L., 2014. Lymphocyte activation in silica-exposed workers. International Journal of Hygiene and Environmental Health 217 (4), 586-591.

Ruckerl, R., Schneider, A., Breitner, S., Cyrys, J., Peters, A., 2011. Health effects of particulate air pollution: a review of epidemiological evidence. Inhal. Toxicol. 23, 555-592.

Samet, J.M., Dominici, F., Curriero, F.C., Coursac, I., Zeger, S.L., 2000. Fine particulate air pollution and mortality in 20 U.S. cities, 1987-1994. N Engl J Med 343, 1742-1749.

Samoli, E., Peng, R., Ramsay, T., Pipikou, M., Touloumi, G., Dominici, F., Burnett, R., Cohen, A., Krewski, D., Samet, J., Katsouyanni, K., 2008. Acute effects of ambient particulate matter on mortality in Europe and North America: results from the APHENA study. Environ. Health Perspect. 116, 1480-1486.

Sharratt, B.S., Lauer, D., 2006. Particulate matter concentration and air quality affected by windblown dust in the Columbia plateau. J. Environ. Qual. 35, 2011-2016.

Soto-Pena, G.A., Luna, A.L., Acosta-Saavedra, L., Conde, P., Lopez-Carrillo, L., Cebrian, M.E., Bastida, M., Calderon-Aranda, E.S., Vega, L., 2006. Assessment of lymphocyte subpopulations and cytokine secretion in children exposed to arsenic. FASEB J. 20, 779-781.

Soukup, D., Buck, B., Goossens, D., Teng, Y., Baron, D., 2011. Mineralogical composition of soil samples in the Nellis Dunes Recreational Area. In: Goossens, D., Buck, B. (Eds.), Assessment of Dust Emissions, Chemistry, and Mineralogy for Management of Natural and Disturbed Surfaces at Nellis Dunes Recreational Area, Nevada, Final Report to Bureau of Land Management for Task Agreement Number FAA010017.

Soukup, D. Buck, B, Goossens, D. Ulery, A. McLaurin, BT, Baron, D. Teng Y., 2012. Arsenic concentrations in dust emissions from wind erosion and off-road vehicles in the Nellis Dunes Recreational Area, Nevada, USA. Aeolian Res. 5, 77-89.
Stanek, L.W., Brown, J.S., Stanek, J., Gift, J., Costa, D.L., 2011. Air pollution toxicology-a brief review of the role of the science in shaping the current understanding of air pollution health risks. Toxicol. Sci. 120 (Suppl. 1), S8-27.

Suta, B.E., 1978. Human exposures to atmospheric arsenic. Center for Resource and Environmental Systems Studies, CRESS Report No. 50.

Tjalve, H., Henriksson, J., 1999. Uptake of metals in the brain via olfactory pathways. Neurotoxicol. 20, 181-195.

Thomas-Schoemann, A., Batteux, F., Mongaret, C., Nicco, C., Chereau, C., Annereau, M., Dauphin, A., Goldwasser, F., Weill, B., Lemare, F., Alexandre, J., 2012. Arsenic trioxide exerts antitumor activity through regulatory $\mathrm{T}$ cell depletion mediated by oxidative stress in a murine model of colon cancer. J. Immunol. 189, 5171-5177.

USEPA. 1988 Arsenic, inorganic (CASRN 7440-38-2) http://www.epa.gov/iris/subst/0278 htm.

USEPA. 2007. Method 6020A. Inductively coupled plasma-mass spectrometry. 6000 series methods. www.epa.gov/osw/hazard/testmethods/sw846/pdfs/6020a.pdf.

Vazquez, M.I., Catalan-Dibene, J., Zlotnik, A., 2015. B cells responses and cytokine production are regulated by their immune microenvironment. Cytokine 74 (2), 318-326.

Wang, J., Hu, Z., Chen, Y., Chen, Z., Xu, S., 2013. Contamination characteristics and possible sources of PM10 and PM2. 5 in different functional areas of Shanghai, China. Atmospheric Environment 68, 221-229.

Whicker, J.J., Pinder III, J.E., Breshears, D.D., Eberhart, C.F., 2006. From dust to dose: effects of forest disturbance on increase inhalation exposure. Sci. Total Environ. 368, 519-530. 